\title{
GEOSPATIAL DISTRIBUTION OF TEPHRA FALL IN ALASKA: A GEODATABASE COMPILATION OF PUBLISHEDTEPHRA FALL OCCURRENCES FROM THE PLEISTOCENETOTHE PRESENT
}

Katherine M. Mulliken, Janet R. Schaefer, Cheryl E. Cameron

Miscellaneous Publication 164

$\$ 5.00$

This publication is PRELIMINARY in nature and meant to allow rapid release of field observations or initial interpretations of geology or analytical data. It has undergone limited peer review, but does not necessarily conform to DGGS editorial standards. Interpretations or conclusions contained in this publication are subject to change.

March 2018

State of Alaska

Department of Natural Resources

Division of Geological \& Geophysical Surveys
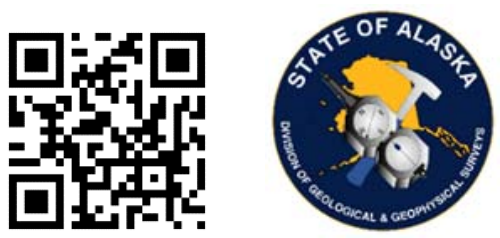

STATE OF ALASKA

Bill Walker, Governor

DEPARTMENT OF NATURAL RESOURCES

Andrew T. Mack, Commissioner

\section{DIVISION OF GEOLOGICAL \& GEOPHYSICAL SURVEYS}

Steve Masterman, State Geologist \& Director

Publications produced by the Division of Geological \& Geophysical Surveys are available for free download from the DGGS website (dggs.alaska.gov). Publications on hard-copy or digital media can be examined or purchased in the Fairbanks office:

\section{Alaska Division of Geological \& Geophysical Surveys (DGGS) 3354 College Road | Fairbanks, Alaska 99709-3707 \\ Phone: 907.451 .5010 | Fax 907.451.5050 \\ dggspubs@alaska.gov | dggs.alaska.gov}

DGGS publications are also available at:

Alaska State Library, Historical

Collections \& Talking Book Center

395 Whittier Street

Juneau, Alaska 99801

Alaska Resource Library and

Information Services (ARLIS)

3150 C Street, Suite 100

Anchorage, Alaska 99503

\section{Suggested citation:}

Mulliken, K.M., Schaefer, J.R., and Cameron, C.E., 2018, Geospatial distribution of tephra fall in Alaska: a geodatabase compilation of published tephra fall occurrences from the Pleistocene to the present: Alaska Division of Geological \& Geophysical Surveys Miscellaneous Publication 164, 46 p. http://doi.org/10.14509/29847
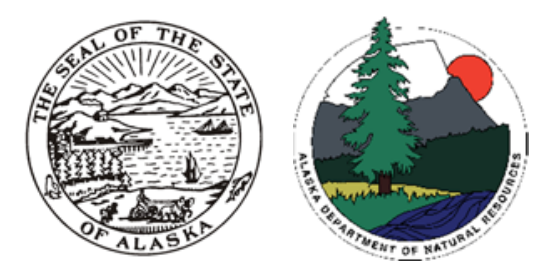



\section{TABLE OF CONTENTS}

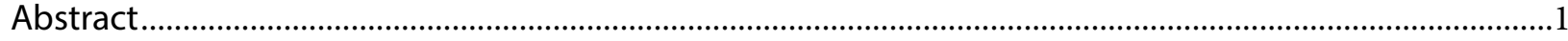

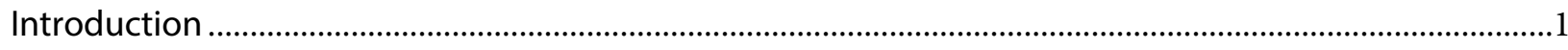

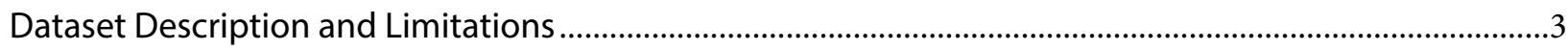

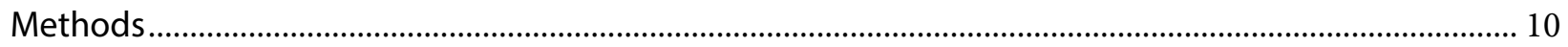

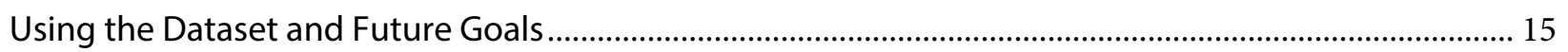

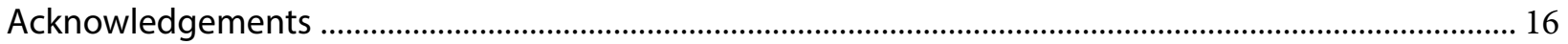

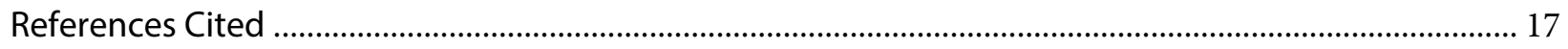

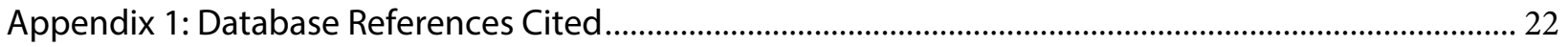

\section{Figures}

Figure 1. Feature classes, relationship classes, and tables in the Alaska tephra geospatial dataset. ..........

Figure 2. Snapshot of the Alaska tephra geospatial dataset..........................................................................4

Figure 3. Example of pre-queried layer files for five of the 39 tephra units with contours and maximum distributions.

Figure 4. Redoubt 1989 tephra footprint polygon (lower) derived from digitized tephra contours (upper), from Scott and McGimsey (1994)..

\section{Tables}

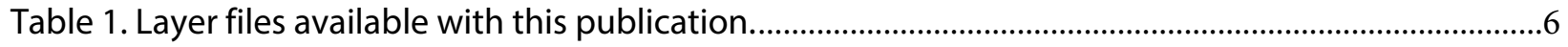

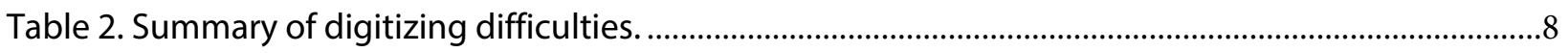

Table 3. alaska_tephra_contours polyline feature class attributes and definitions................................... 11

Table 4. alaska_tephra_footprints polygon feature class attributes and definitions............................... 12

Table 5. geodiva_stations_12072017 point feature class attributes and definitions................................. 12

Table 6. table_geodiva_samples_12072017 attributes and definitions....................................................... 13

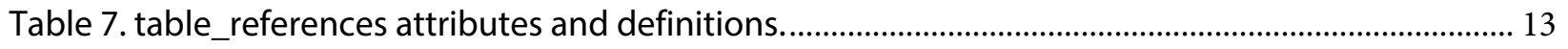

Table 8. table_Alaska_tephra_contours_figures attributes and definitions............................................... 13 



\title{
GEOSPATIAL DISTRIBUTION OF TEPHRA FALL IN ALASKA: A GEODATABASE COMPILATION OF PUBLISHEDTEPHRA FALL OCCURRENCES FROM THE PLEISTOCENE TOTHE PRESENT
}

Katherine M. Mulliken ${ }^{1}$, Janet R. Schaefer ${ }^{1}$, Cheryl E. Cameron ${ }^{1}$

\begin{abstract}
Tephra fall (volcanic ash) studies are a key component to understanding the frequency and magnitude of volcanic eruptions and conducting volcano-hazard assessments. In addition, many interdisciplinary studies rely on tephra fall deposits as time-stratigraphic markers. Information on tephra deposits in Alaska has previously been dispersed amongst hundreds of publications that span numerous research disciplines. In order to streamline tephra occurrence data, information from these disparate publications have been compiled into one comprehensive geospatial dataset. Pleistocene, Holocene, and historical tephra deposit distribution information has been digitized for more than 120 published resources, including peer-reviewed articles, reports, and theses/dissertations. The dataset includes tephra fall distribution information pertaining to 39 eruptions from at least 19 volcanoes in Alaska.
\end{abstract}

\section{INTRODUCTION}

Tephra fall describes products of an explosive volcanic eruption, which travel through the air before being deposited. These products may range in size and density with larger, denser particles generally falling out near the vent and smaller particles such as volcanic ash $(<2 \mathrm{~mm})$ traveling tens to hundreds of kilometers distally. Once deposited, tephra fall can be preserved in the geologic record by burial and/or soil development. The area of deposition depends on the size of the eruption and wind direction and strength at the time of the eruption. Typically, a fall deposit from an explosive eruption will decrease in thickness with distance from the source. Tephra fall deposits are mapped as contours of equal deposit thickness (isopach), equal mass-per-unit area (isomass), or equal maximum grain-size (isopleth).

In Alaska, there are over 100 volcanoes, 54 of which have been active historically (Cameron and Schaefer, 2016), and numerous tephra fall deposits of various ages are found throughout the state. For decades, researchers in fields such as volcanology, paleoenvironmental studies, and archaeology have encountered tephra deposits in Alaska and published data on those occurrences. Tephra fall data reporting is not standardized, thus the amount and types of information recorded vary among publications. Digitally accessible formats, especially geospatial data of tephra occurrences and aerial distribution, are increasingly useful for multidisciplinary studies (e.g., Mastin and others, 2013; Schaefer and Wallace, 2012; Schaefer, 2015; Wallace and others, 2013). Tephra fall occurrence data includes dispersion area, contours describing deposit thickness, maximum particle size, or mass-per-unit area, locations of occurrence and physical descriptions.

\footnotetext{
${ }^{1}$ State of Alaska, Department of Natural Resources, Division of Geological \& Geophysical Surveys, 3354 College Road, Fairbanks, AK 99709-3707
} 
This report provides Alaska tephra fall occurrence data readily accessible in one location and in digital geospatial format.

\section{DATASET DESCRIPTION AND LIMITATIONS}

This dataset contains an ESRI ArcGIS file geodatabase with established relationship classes (Figures 1 and 2). There are five feature classes, three tables, and five relationship classes. Three feature classes are newly published here (digitized based on previously published information), and two previously published datasets are included as references (Cameron and Schaefer, 2016; Cameron and Nye, 2014). In addition, a layer file symbolizing all digitized data is provided, as well as layer files for each tephra unit with published contours (Table 1 and Figure 3), with pre-defined queries for relevant data. Layer files group relevant data for each tephra unit from multiple feature classes and preserve the path to the source data while retaining the symbology and selection. Included in this publication is a map document with all layer files. As a default, the map document opens with the "Alaska Tephra All" layer displayed, which symbolizes all data in the geodatabase. By using the "List By Drawing Order" option in the map document Table Of Contents, the user can choose to display layers that symbolize deposits of interest. All data are projected using Alaska Albers and the 1983 North American Datum.

- Feature Classes:

o alaska_tephra_contours: polylines representing digitized tephra fall contours;

o alaska_tephra_footprints: polygons representing maximum tephra fall distribution extents;

o geodiva_stations_12072017: points that represent tephra sample locations;

o Previously published reference feature classes:

- alaska_historically_active_volcanoes: points for locations of the 54 historically active volcanoes in Alaska (Cameron and Schaefer, 2016);

- alaska_quaternary_volcanic_vents: points for the volcanic vents in Alaska that have been active in the Quaternary Period (Cameron and Nye, 2014).

- Tables:

o table_geodiva_samples_12072017: list of tephra samples and metadata;

o table_references: list of references for all digitized data;

o table_alaska_tephra_contours_figures: list of figures with data that was digitized, with figures attached for user reference.

- Relationship Classes (associate feature classes or tables to each other):

o relationship_contours_have_figures;

o relationship_contours_have_references;

o relationship_footprints_have_references;

o relationship_samples_have_references;

o relationship_stations_have_samples. 


\begin{tabular}{l}
\hline geodiva_stations_12072017 [Points] \\
OBJECTID [ObjectID] \\
SHAPE [Geometry] \\
stationid [Text] \\
lat_nad83 [Double] \\
long_nad83 [Double] \\
geologist [Text] \\
volcano [Text] \\
visit_date [Text] \\
stationdes [Text] \\
stationcom [Text]
\end{tabular}

$\mid$

\begin{tabular}{|l}
\hline alaska_tephra_footprints [Po \\
OBJECTID [ObjectID] \\
SHAPE [Geometry] \\
tephraname [Text] \\
sourcevolc [Text] \\
citations [Text] \\
age_epoch [Text] \\
best_age [Text] \\
age_cit [Text] \\
age_notes [Text] \\
prox_desc [Text] \\
prox_cit [Text] \\
dist_desc [Text] \\
dist_cit [Text] \\
comments [Text] \\
footprntid [Double] \\
Shape_Length [Double] \\
Shape_Area [Double]
\end{tabular}
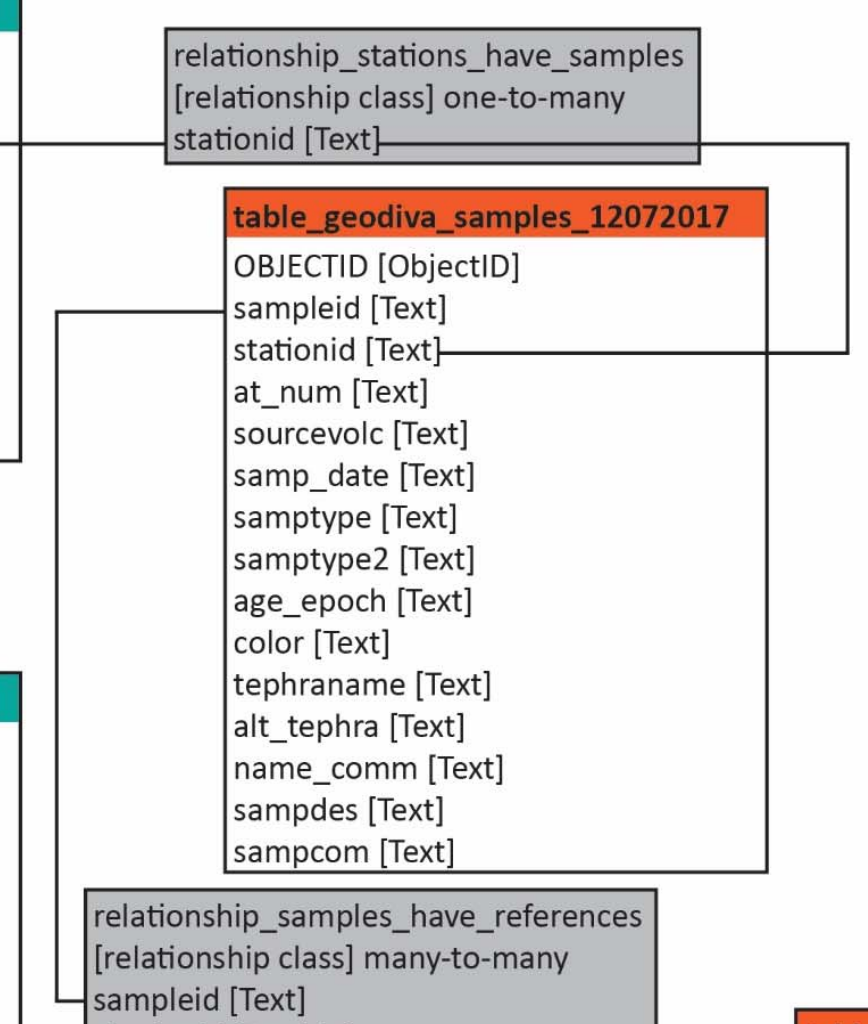

relationship_samples_have_references [relationship class] many-to-many sampleid [Text] citationid [Double]__able_references

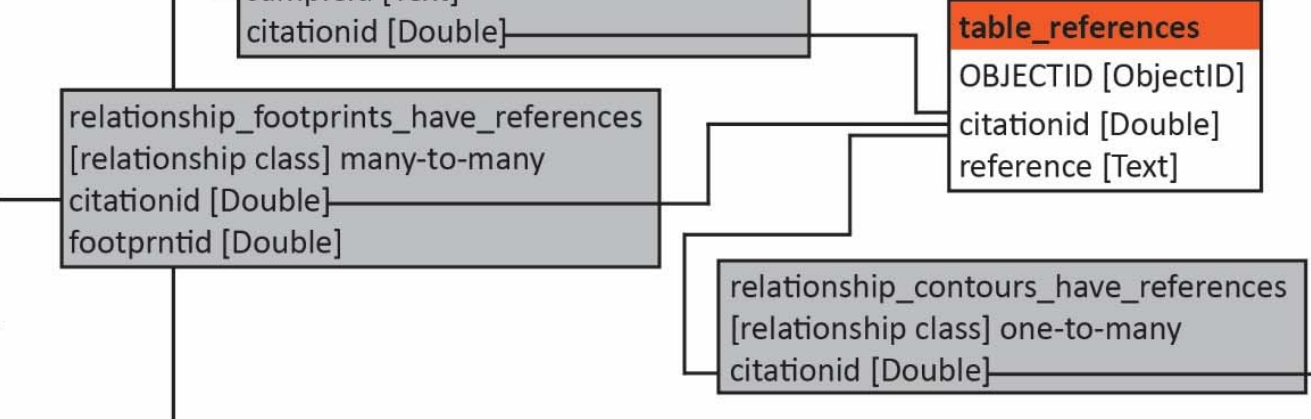

table alaska tephra contours figures ATTACHMENTID [Object ID] REL_OBJECTID [Long Integer] CONTENT_TYPE [Text] ATT_NAME [Text]

DATA_SIZE [Long Integer] DATA [Blob]

relationship_contours_have_figures [relationship class] one-to-one REL_OBJECTID [Long Integer] OBJECTID [ObjectID]

alaska_tephra_contours [Polylines] OBJECTID [ObjectID] SHAPE [Geometry] tephraname [Text] sub_unit [Text] sourcevolc [Text] isopach_cm [Text] mass_gm 2 [Text] pleth_cm [Text] map_info [Text] comments [Text] citation [Text] age_epoch [Text] age_in_ref [Text] best_age [Text] age_cit [Text] age_notes [Text] fig_num [Text] fig_scale [Text] other_cits [Text] citationid [Double] SHAPE_Length [Double]

Figure 1. Feature classes, relationship classes, and tables in the Alaska tephra geospatial dataset. Feature classes are green, tables are orange, and relationship classes are grey. Data types are noted in brackets. Previously published reference datasets, Alaska historically active volcanoes (Cameron and Schaefer, 2016) and Alaska quaternary vents (Cameron and Nye, 2014), are not included because they are standalone datasets without relationship classes. 


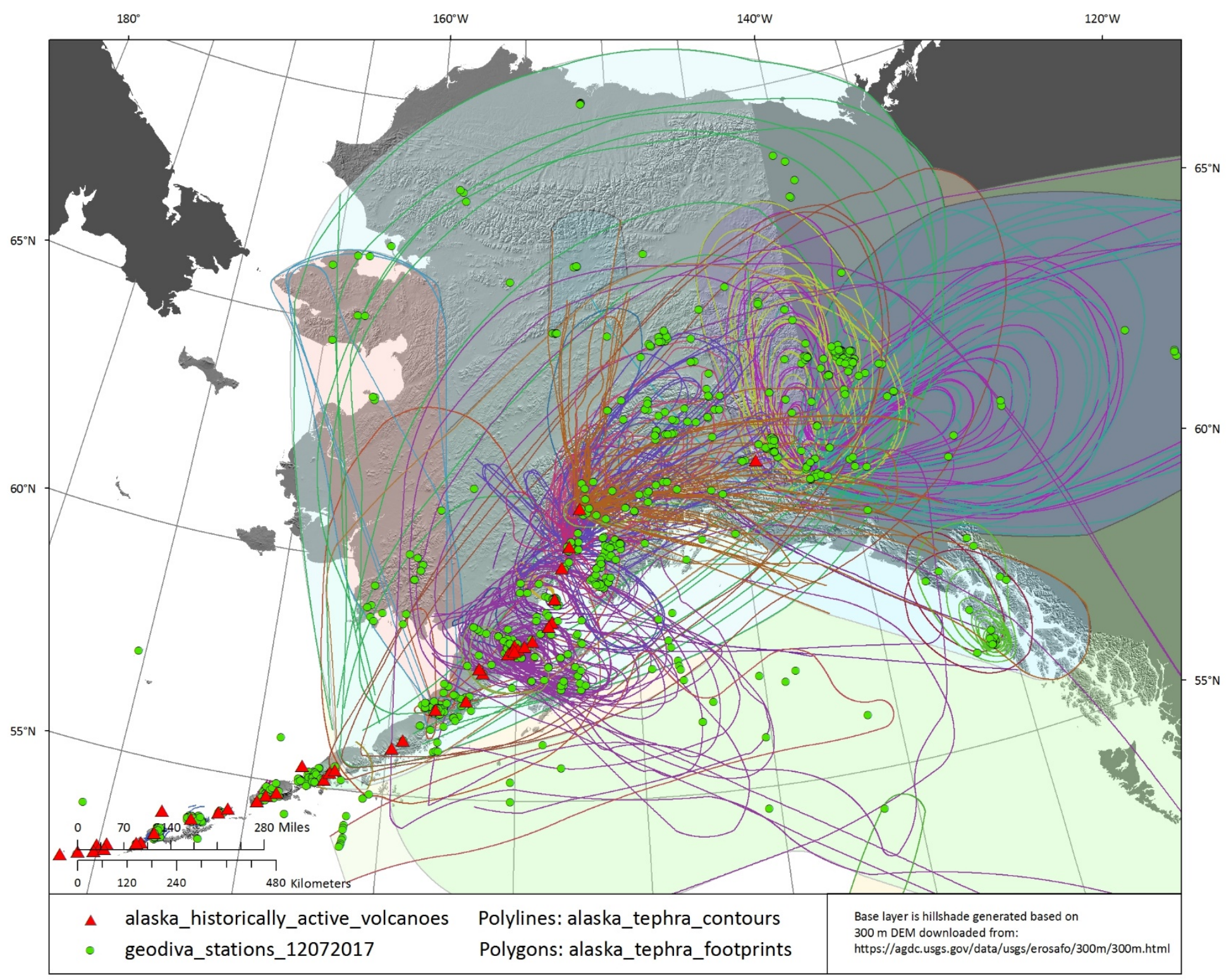

Figure 2. Snapshot of the Alaska tephra geospatial dataset. The dataset contains tephra contour lines, tephra footprints, and stations with tephra samples. 
Table 1. Layer files available with this publication. Layer files include pre-queried data on deposit contours, maximum distribution footprints, tephra sample locations, and vent locations; one layer file includes all data. The layer files listed here represent only a subset of the data found in the geodatabase.

\begin{tabular}{|c|c|c|}
\hline Layer (deposit) Name & Deposit Age & Age Reference \\
\hline Alaska Tephra All (all data in database) & N/A & N/A \\
\hline $\begin{array}{l}\text { Aniakchak } 1931 \\
\text { Aniakchak II CFE }\end{array}$ & $\begin{array}{l}1931 \mathrm{CE} \\
3430 \pm 70{ }^{14} \mathrm{C} \text { yr BP }\end{array}$ & $\begin{array}{l}\text { Alaska historical } \\
\text { Bacon and others (2014) }\end{array}$ \\
\hline Augustine 2006 & $2006 \mathrm{CE}$ & Alaska historical \\
\hline Augustine 1976 & $1976 \mathrm{CE}$ & Alaska historical \\
\hline Augustine Tephra B & $390{ }^{14} \mathrm{C}$ yr BP ${ }^{1}$ & Waitt and Begét (2009) \\
\hline Augustine Tephra M & $750{ }^{14} \mathrm{Cyr} \mathrm{BP}^{1}$ & Waitt and Begét (2009) \\
\hline Augustine Tephra C & $1200-1000{ }^{14} C_{\text {yr BP }}{ }^{1}$ & Waitt and Begét (2009) \\
\hline Augustine Tephra H & $1500-1400{ }^{14} \mathrm{C}_{\mathrm{jr} \mathrm{BP}}{ }^{1}$ & Waitt and Begét (2009) \\
\hline Augustine Tephra I & $1700{ }^{14} \mathrm{C} \mathrm{yr} \mathrm{BP}{ }^{1}$ & Waitt and Begét (2009) \\
\hline $\begin{array}{l}\text { Crater Peak, Spurr } 1992 \\
\text { Crater Peak, Spurr } 1953\end{array}$ & $\begin{array}{l}1992 \mathrm{CE} \\
1953 \mathrm{CE}\end{array}$ & $\begin{array}{l}\text { Alaska historical } \\
\text { Alaska historical }\end{array}$ \\
\hline Drum Sheep Creek Tephra-F & $190,000 \pm 20,000$ yr BP 2 & Berger and others (1996) \\
\hline $\begin{array}{l}\text { Edgecumbe Dacite (MED) } \\
\text { Edgecumbe Tephra Set }\end{array}$ & $\begin{array}{l}11,250 \pm 50{ }^{14} \mathrm{C} \text { yr BP } \\
11,300-12,000{ }^{14} \mathrm{C} \text { yr BP }\end{array}$ & $\begin{array}{l}\text { Begét and Motyka (1998) } \\
\text { Riehle and others (1992) }\end{array}$ \\
\hline $\begin{array}{l}\text { Emmons Lake Volcanic Center Dawson Tephra- } \\
\text { C2 CFE }\end{array}$ & $24,000{ }^{14} \mathrm{C} \mathrm{yr} \mathrm{BP}^{1}$ & Froese and others (2002) \\
\hline Emmons Lake Volcanic Center Old Crow Tephra & $124,000 \pm 10,000{ }^{14} \mathrm{C} \mathrm{yr} \mathrm{BP}^{3}$ & Preece and others (2011) \\
\hline $\begin{array}{l}\text { Fisher Maar } \\
\text { Fisher Funk Ash CFE }\end{array}$ & $\begin{array}{l}\text { Recent } \\
9372 \pm 198{ }^{14} \mathrm{C} \text { yr BP }\end{array}$ & $\begin{array}{l}\text { Stelling (2003) } \\
\text { Stelling (2003) }\end{array}$ \\
\hline $\begin{array}{l}\text { Hayes Oshetna Tephra } \\
\text { Hayes Tephra Set H }\end{array}$ & $\begin{array}{l}6000{ }^{14} \mathrm{C} \text { yr BP }{ }^{1} \text { - Oshetna } \\
3750 \pm 30-3200 \pm 30{ }^{14} \mathrm{C} \text { yr BP }\end{array}$ & $\begin{array}{l}\text { Child and others (1998) } \\
\text { Wallace and others (2014); } \\
\text { Mulliken (2016) }\end{array}$ \\
\hline Kaguyak CFE & $5800{ }^{14} \mathrm{C}$ yr BP ${ }^{1}$ & Fierstein (2007) \\
\hline Katmai Lethe Assemblage & $12,000-16,000{ }^{14} \mathrm{C}$ yr BP & Fierstein (2007) \\
\hline $\begin{array}{l}\text { Mageik Orange Dacite Lapilli } \\
\text { Mageik Lower Grey Ash }\end{array}$ & $\begin{array}{l}3800-4000{ }^{14} \mathrm{C} \text { yr BP } \\
3600{ }^{14} \mathrm{C}_{\text {yr BP }}\end{array}$ & $\begin{array}{l}\text { Fierstein (2007) } \\
\text { Fierstein (2007) }\end{array}$ \\
\hline Makushin Driftwood Pumice & $5070-7740{ }^{14} \mathrm{C}$ yr BP & Bean (1999) \\
\hline $\begin{array}{l}\text { Mt. Churchill White River Ash-North } \\
\text { Mt. Churchill White River Ash-East } \\
\text { Mt. Churchill White River Ash-all }\end{array}$ & $\begin{array}{l}1900{ }^{14} \mathrm{C} \mathrm{yr} \mathrm{BP}^{1} \\
1147 \text { cal yr BP } \\
\text { North and East deposits }\end{array}$ & $\begin{array}{l}\text { Preece and others (2014) } \\
\text { Clague and others (1995) } \\
\text { N/A }\end{array}$ \\
\hline Novarupta 1912 CFE & $1912 \mathrm{CE}$ & Alaska historical \\
\hline $\begin{array}{l}\text { Okmok } 2008 \\
\text { Okmok Middle Scoria }\end{array}$ & $\begin{array}{l}2008 \mathrm{CE} \\
12,000-2050 \pm 50{ }^{14} \mathrm{C} \text { yr BP }\end{array}$ & $\begin{array}{l}\text { Alaska historical } \\
\text { Begét and others (2005) }\end{array}$ \\
\hline Pavlof general & General & Alaska historical \\
\hline Redoubt 2009 & $2009 \mathrm{CE}$ & Alaska historical \\
\hline Redoubt 1989-1990 & $1989 \mathrm{CE}$ & Alaska historical \\
\hline Redoubt 1966 & 1966 CE & Alaska historical \\
\hline Shishaldin 1999 & $1999 \mathrm{CE}$ & Alaska historical \\
\hline Ukinrek Maars 1977 & $1977 \mathrm{CE}$ & Alaska historical \\
\hline $\begin{array}{l}\text { Unknown vent Middle Basic Layer } \\
\text { Unknown vent Lower Ash Layer } \\
\text { Unknown vent Variegated Tephra }\end{array}$ & $\begin{array}{l}15,000-12,000 \mathrm{yrs}^{5} \\
30,000-25,800 \pm 1300{ }^{14} \mathrm{C} \text { yr BP } \\
106,000 \pm 10,000 \mathrm{yr} \mathrm{BP}^{6}\end{array}$ & $\begin{array}{l}\text { Nayudu (1964) } \\
\text { Nayudu (1964) } \\
\text { Jensen and others (2011) }\end{array}$ \\
\hline
\end{tabular}

All ages are Alaska historical or uncalibrated radiocarbon years before present $\left({ }^{14} \mathrm{C}\right.$ yr BP) unless otherwise noted. ${ }^{1}$ Error not reported for deposit age; ${ }^{2}$ thermoluminescence age; ${ }^{3}$ glass fission-track age; ${ }^{4}$ Clague and others (1995) only report the calibrated age range for the Mt. Churchill White River Ash-East deposit; ${ }^{5} \mathrm{Nayudu}$ (1964) bases the age estimate of the Unknown vent Middle Basic Layer on stratigraphy; ${ }^{6}$ infrared stimulated luminescence age. 

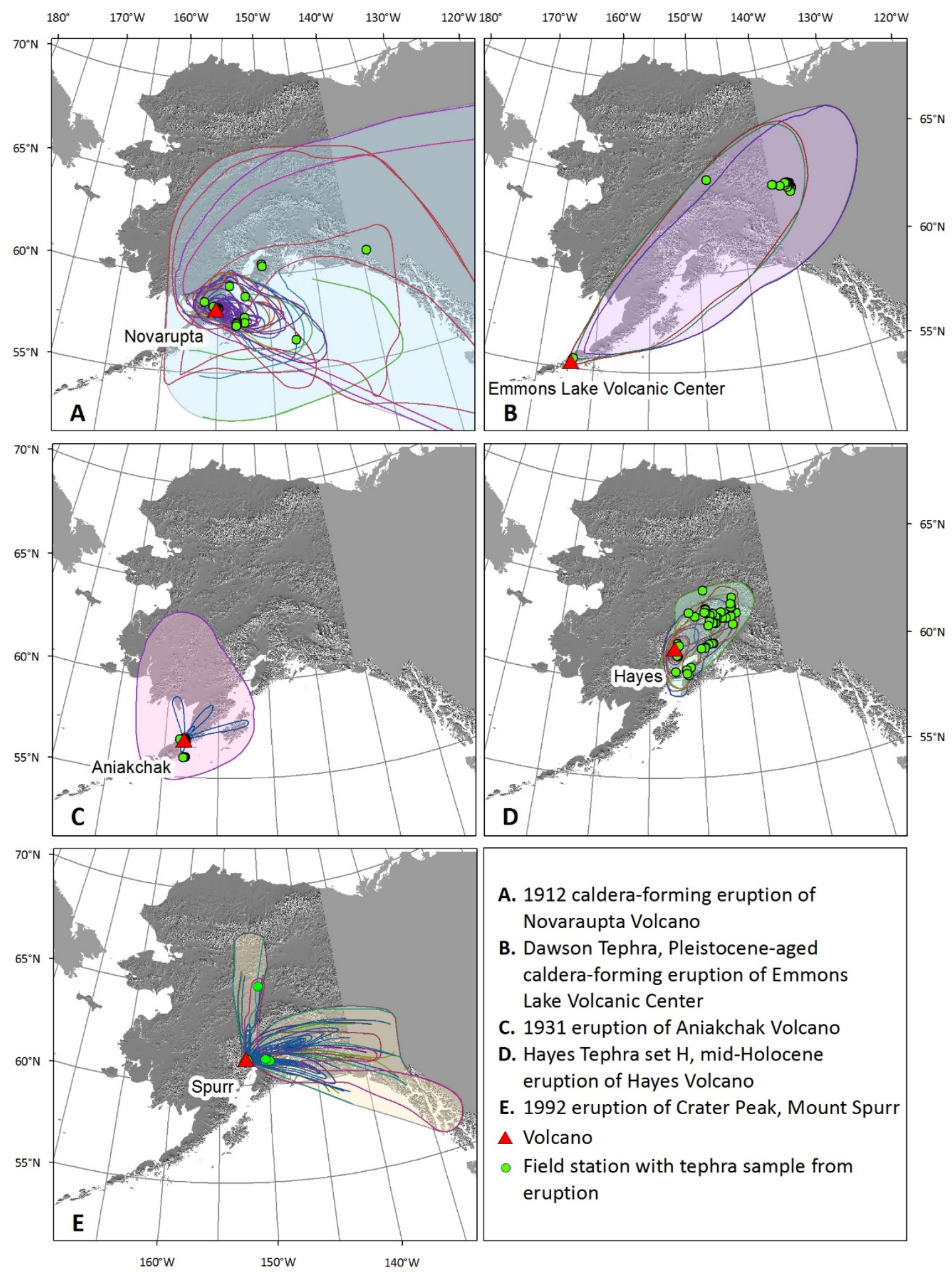

A. 1912 caldera-forming eruption of Novaraupta Volcano

B. Dawson Tephra, Pleistocene-aged caldera-forming eruption of Emmons Lake Volcanic Center

C. 1931 eruption of Aniakchak Volcano

D. Hayes Tephra set $\mathrm{H}$, mid-Holocene eruption of Hayes Volcano

E. 1992 eruption of Crater Peak, Mount Spurr

A Volcano

- Field station with tephra sample from eruption

Figure 3. Example of pre-queried layer files for five of the 39 tephra units with contours and maximum distributions. Pre-queried layer file displays can be accessed easily in the ArcMap document by selecting the "List by Drawing Order" icon in the Table of Contents, and toggling the layers on or off. 
Approximately 700 tephra fall contour lines have been digitized, pertaining to 39 eruptions from at least 19 volcanoes. For each tephra unit with contours or other distributional data, a tephra fall footprint polygon was derived, which describes the approximate maximum interpreted distribution of that unit. In addition, approximately 4,500 tephra samples collected from approximately 1,600 stations were exported from the Alaska Tephra Database module of the Alaska Volcano Observatory's Geologic Database of Information on Volcanoes in Alaska (GeoDIVA) (Cameron and others, 2015; Cameron and others 2016a; Cameron and others 2016b) on December 7, 2017, and are included in this dataset. For this publication, we have named the feature class (stations) and table (tephra samples) exported from GeoDIVA with a query date, e.g., "geodiva_stations_12072017" indicates the station point features were queried from GeoDIVA on December 7, 2017. The full bibliographic references for all data are contained in the references table.

This dataset is a compilation of data from numerous publications and thus has limitations. The accuracy of tephra deposit contours is dependent on the original publications from which the tephra fall distributional data were digitized. Table 2 presents a list of references with figures that were difficult to digitize and tephra fall unit footprints that were difficult to derive. Geospatial accuracy issues arose when contours and sample locations were digitized from very small, manually georeferenced illustrations and map figures. However, these accuracy issues have been mitigated by using landmark cities, vent locations, major geographic features, geopolitical boundaries, roads, and rivers as a means to quality-control digitization of data from small illustrations and maps.

Occasionally, ashfall contours from the same eruption(s) appear in multiple publications. Where those contours are notably different in shape and size, the contours were digitized from multiple publications. However, in some instances, the ashfall contours from the same eruption(s) were essentially identical between publications and therefore, in order to avoid dataset duplications, only the original reference reporting the ashfall contour was digitized. The additional publications that report duplicate ashfall contours are noted in the "other_refs" field in the "alaska_tephra_contours" polyline feature class.

Individual publications report geochronologic information in different ways, with no uniform standards, resulting in a variety of formats that make it difficult to design query-friendly age data fields. In addition, as eruption histories are refined with more study and improved dating techniques, so are the ages of specific tephra deposits. Therefore, in this report, we present ages from the original reference that the contour was digitized from, as well as a "best age." Sometimes the original reference is the only age reported and therefore it is also the best age. However, the best age may alternatively be from a more recent publication (i.e., the date reported in the publication with the tephra geospatial information is no longer an accepted age for that deposit/eruption). Ages listed in this dataset are meant to guide researchers, who are encouraged to refer to original publications for more detail on deposit geochronology. 
Table 2. Summary of digitizing difficulties.

\begin{tabular}{|c|c|}
\hline Reference(s) & Difficulty \\
\hline $\begin{array}{l}\text { Begét and others (1992); Moodie and } \\
\text { others (1992); Clague and others } \\
\text { (1995); West and Donaldson (2001); } \\
\text { West (2007); Jensen (2007); Lerbekmo } \\
\text { (2008); Dunning (2011); Mullen (2012) }\end{array}$ & $\begin{array}{l}\text { The Mt. Churchill White River Ash-all tephra footprint has a very } \\
\text { irregular boundary that is not reflective of the actual deposit, but } \\
\text { rather the contours that the deposit footprint was derived from. The } \\
\text { irregular boundaries have been smoothed for the individual White } \\
\text { River Ash East and North lobe deposit footprints. }\end{array}$ \\
\hline Berger and others (1996) & $\begin{array}{l}\text { Berger and others provide a rough approximation of the distribution } \\
\text { of the Drum Sheep Creek Tephra-F. The tephra footprint is undefined } \\
\text { north of the footprint polygon, which is why the west-east } \\
\text { boundaries are sharp (not reflective of the actual deposit). }\end{array}$ \\
\hline $\begin{array}{l}\text { Child and others (1998); Davies and } \\
\text { others (2016) }\end{array}$ & $\begin{array}{l}\text { The Hayes Oshetna Tephra footprint has a bilobate distribution due } \\
\text { to two differing published distributions. It is unknown whether the } \\
\text { actual deposit is bilobate. }\end{array}$ \\
\hline , figure 4.9 & There were few landmarks on the figure to aid in georeferencing. \\
\hline $\begin{array}{l}\text { Fierstein and Hildreth (1992), figures 5, } \\
14 \text {, and } 16\end{array}$ & There were few landmarks on the figure to aid in georeferencing. \\
\hline Fierstein (2007) & $\begin{array}{l}\text { The Mageik Orange Dacite Lapilli Fall and Mageik Lower Grey Ash } \\
\text { tephra footprints have sharp corners that are not actually reflective } \\
\text { of the deposits, but rather the contours the deposit footprints were } \\
\text { derived from. }\end{array}$ \\
\hline Fierst & \\
\hline $\begin{array}{l}\text { Johnston (1978); Kienle and Swanson } \\
\text { (1983); Fierstein and Hildreth (2001); } \\
\text { de Fontaine (2003); Stevens (2012) }\end{array}$ & $\begin{array}{l}\text { The Augustine } 1976 \text { eruption footprint has sharp corners that are not } \\
\text { actually reflective of the deposit but represent the intersection of } \\
\text { contours the footprint was derived from. }\end{array}$ \\
\hline $\begin{array}{l}\text { Larsen and others (2015); Unema and } \\
\text { others (2016) }\end{array}$ & $\begin{array}{l}\text { The Okmok } 2008 \text { eruption footprint has a very irregular boundary } \\
\text { that is not actually reflective of the deposit, but rather the contours } \\
\text { the footprint was derived from. }\end{array}$ \\
\hline $\begin{array}{l}\text { Nicholson (2003) figures } 10,11,12 \text {, and } \\
13\end{array}$ & There were few landmarks on the figure to aid in georeferencing. \\
\hline $\begin{array}{l}\text { Riehle and others (1998); Fierstein and } \\
\text { Hildreth (2008) }\end{array}$ & $\begin{array}{l}\text { The Kaguyak CFE deposit footprint comes to a point along its } \\
\text { southern margin; this is not reflective of the actual deposit, but rather } \\
\text { the contours the deposit footprint was derived from. }\end{array}$ \\
\hline $\begin{array}{l}\text { Stelling (2003); Stelling and others } \\
\text { (2005); Gardner and others (2007); } \\
\text { Stelling and others (2014) }\end{array}$ & $\begin{array}{l}\text { The Fisher CFE tephra footprint is derived from multiple references } \\
\text { with sharp contour boundaries, resulting in an odd tephra footprint } \\
\text { polygon with sharp boundaries. }\end{array}$ \\
\hline Waitt and Begét (2009) & $\begin{array}{l}\text { The Augustine Tephras } \mathrm{B}, \mathrm{C}, \mathrm{H}, \mathrm{I} \text {, and } \mathrm{M} \text { footprints have sharp } \\
\text { boundaries not actually reflective of the deposits, due to the tephra } \\
\text { contours the footprints were derived from. }\end{array}$ \\
\hline $\begin{array}{l}\text { Waythomas and others (2006); } \\
\text { Waythomas (2015) }\end{array}$ & $\begin{array}{l}\text { The Pavlof general tephra footprint is not eruption-specific but does } \\
\text { provide an estimate for the distribution of general Pavlof tephra. }\end{array}$ \\
\hline $\begin{array}{l}\text { Wilcox (1959); Kienle and Swanson } \\
\text { (1983); Waythomas and Nye (2002) }\end{array}$ & $\begin{array}{l}\text { The Crater Peak, Spurr } 1953 \text { tephra footprint has a very irregular } \\
\text { shape that is not reflective of the actual deposit, but rather the } \\
\text { tephra contours that the footprint was derived from. }\end{array}$ \\
\hline $\begin{array}{l}\text { Wong (2004) figures } 9,10,11,13 \text {, and } \\
14 ; \text { Wong and Larsen }(2010) \text { figures } 5 \\
\text { and } 6\end{array}$ & $\begin{array}{l}\text { There were slight differences in contour placement and contours } \\
\text { present on figures between these two references. For digitization, } \\
\text { Wong (2004) was preferred, with additional contours digitized from } \\
\text { Wong and Larsen (2010) if they were absent from Wong (2004). }\end{array}$ \\
\hline
\end{tabular}


Lastly, as new publications are released that contain tephra distribution data, this dataset compilation will become outdated. The GeoDIVA Alaska Tephra Database is continually updated. Therefore, the static station and samples exported from GeoDIVA on December 7, 2017, and incorporated in this database will eventually be non-comprehensive. We intend to update this dataset to incorporate new data as new datasets are published.

\section{METHODS}

As part of an extensive literature review undertaken during population of the Alaska Tephra Database, more than 100 publications containing illustrations or maps with information on the occurrence and distribution of tephra in Alaska were identified. From these publications, approximately 225 figures were saved as individual JPEGs, georeferenced, and contours on the figures were digitized. Tephra contours, footprints, and occurrences were digitized as individual polylines, polygons, and point shapefiles, which were compiled into an ESRI ArcGIS file geodatabase. Relevant metadata garnered from the original publications are documented in tables that now reside in the geodatabase and have established relationships with a table that contains the full references. Users of this dataset are encouraged to refer to the original references for additional information on the deposits. A list of the attributes included in each feature class, and their definitions, are described in Tables 3-8.

Tephra contours are associated with the full references they were digitized from in a oneto-one relationship class with the reference table based on the "citationid" field. The geodatabase stores the published figures that contours were digitized from in the "alaska_tephra_contours_figures" table, with which the contours feature class has a one-to-one relationship class. This allows the user to reference the original figure from which a contour was digitized.

From the digitized contours, maximum distribution tephra "footprints" of each applicable unit were derived and saved as polygons (Figure 4). The maximum distribution tephra "footprints" have a many-to-many relationship class with the references table, i.e., a maximum distribution polygon for a tephra deposit can be derived from more than one reference and a reference could have provided information used to derive more than one maximum tephra distribution polygon.

In order to incorporate distinct tephra occurrences in Alaska, sample and station data tables were exported from the Alaska Tephra Database module of GeoDIVA and incorporated into this dataset. The Alaska Tephra Database is a comprehensive repository for Alaska tephra data and includes sample and station information, chemical analyses, age information and eruption data for published tephra samples, as well as previously unpublished tephra samples collected by Alaska Volcano Observatory (AVO) scientists. Only published stations (geodiva_stations_12072017 point feature class) and tephra samples (table_geodiva_samples_12072017) of known location are included in this dataset, and all data were exported on December 7, 2017. Tephra samples and their stations are associated via a one-to-many relationship class based on the "stationid" field, i.e., one station can have many tephra samples. Using the "sampleid" field, samples have a many-to-many 
relationship with their references stored in the references table, i.e., one tephra sample can have many references and one reference may contain many tephra samples.

Table 3. alaska_tephra_contours polyline feature class attributes and definitions.

\begin{tabular}{|c|c|}
\hline Attribute Field [data type] & Description \\
\hline OBJECTID [ObjectID] & ArcGIS-generated numeric identifier. \\
\hline SHAPE [Geometry] & ArcGIS-generated geometry. \\
\hline tephraname [Text] & Informal name of the tephra unit. \\
\hline sub_unit [Text] & $\begin{array}{l}\text { Contour specific to a subset of the tephra unit (e.g., differences within a deposit } \\
\text { thought to represent a specific phase of an eruption, a specific day during a historical } \\
\text { eruption, or a distinct feature of a deposit thought to represent a change in the } \\
\text { eruption). Value is blank if the contour describes the unit as a whole. }\end{array}$ \\
\hline sourcevolc [Text] & If the tephra unit has a known potential source vent. \\
\hline isopach_cm [Text] & Contour line denotes isopach (equal deposit thickness), given in $\mathrm{cm}$. \\
\hline mass_gm2 [Text] & $\begin{array}{l}\text { Contour line denotes isomass (equal mass-per-unit-area of tephra fall), in grams per } \\
\text { square meter. }\end{array}$ \\
\hline pleth_cm [Text] & $\begin{array}{l}\text { Contour line denotes isopleth (equal maximum grain size, pumice size, or lithic size } \\
\text { deposition), given in } \mathrm{cm} \text { (if given, particle type is noted in the map_info field). }\end{array}$ \\
\hline map_info [Text] & $\begin{array}{l}\text { If the digitized map or illustration contained additional useful metadata, it is detailed } \\
\text { here. }\end{array}$ \\
\hline comments [Text] & Comments by the digitizer. \\
\hline citation $[$ Text] & Citation for the reference that the contour was digitized from. \\
\hline age_epoch [Text] & Age epoch of the deposit/eruption (Pleistocene, Holocene, Alaska historical). \\
\hline age_in_ref [Text] & $\begin{array}{l}\text { Age of deposit/eruption as reported in the reference that the contour is digitized } \\
\text { from. }\end{array}$ \\
\hline best_age [Text] & $\begin{array}{l}\text { This value may be a deposit age estimate provided in a more recent reference or may } \\
\text { be the same as the age estimate provided in the reference that the contour was } \\
\text { digitized from. }\end{array}$ \\
\hline age_cit [Text] & Citation for the reference of the age reported in the best_age field. \\
\hline age_notes [Text] & Comments on the age determination of the tephra deposit. \\
\hline fig_num [Text] & Figure number that the contour was digitized from, in the original reference. \\
\hline fig_scale [Text] & Scale of the figure that the contour was digitized from, in the original reference. \\
\hline other_cits [Text] & A list of citations for other references that the contour has appeared in. \\
\hline citationid [Double] & $\begin{array}{l}\text { Unique numeric identifier that allows the contour to be linked with the reference it } \\
\text { was digitized from. }\end{array}$ \\
\hline SHAPE_Length [Double] & ArcGIS-generated shape length (in meters). \\
\hline
\end{tabular}


Table 4. alaska_tephra_footprints polygon feature class attributes and definitions.

\begin{tabular}{|c|c|}
\hline Attribute Field [data type] & Description \\
\hline OBJECTID [ObjectID] & ArcGIS-generated identifier. \\
\hline SHAPE [Geometry] & ArcGIS-generated geometry. \\
\hline tephraname [Text] & Informal name of the tephra unit. \\
\hline sourcevolc [Text] & If the tephra unit has a potential source vent. \\
\hline citations [Text] & A list of citations for the references that the footprint was derived from. \\
\hline age_epoch [Text] & Age epoch of the deposit/eruption (Pleistocene, Holocene, Alaska historical). \\
\hline best_age [Text] & $\begin{array}{l}\text { This value may be a deposit age estimate provided in a more recent reference or may } \\
\text { be the same as the age estimate provided in the reference that the contour was } \\
\text { digitized from. }\end{array}$ \\
\hline age_cit [Text] & Citation for the reference of the age reported in the best_age field. \\
\hline age_notes [Text] & Comments on the age determination of the tephra deposit. \\
\hline prox_desc [Text] & If available, a proximal description of the deposit. \\
\hline prox_cit [Text] & Citation for the reference of the proximal deposit description. \\
\hline dist_desc [Text] & If available, a distal description of the deposit. \\
\hline dist_cit [Text] & Citation for the reference of the distal deposit description. \\
\hline comments [Text] & Comments by the digitizer. \\
\hline footprntid [Double] & $\begin{array}{l}\text { Unique numeric identifier that allows the footprint to be linked with the references } \\
\text { that it was derived from. }\end{array}$ \\
\hline SHAPE_Length [Double] & ArcGIS-generated shape length (in meters). \\
\hline SHAPE_AREA [Double] & ArcGIS-generated shape area (in square meters). \\
\hline
\end{tabular}

Table 5. geodiva_stations_12072017 point feature class attributes and definitions.

\begin{tabular}{|c|c|}
\hline Attribute Field [data type] & Description \\
\hline OBJECTID [ObjectID] & ArcGIS-generated identifier. \\
\hline SHAPE [Geometry] & ArcGIS-generated geometry. \\
\hline stationid [Text] & $\begin{array}{l}\text { The alphanumeric descriptor of the sample's station. For samples published without } \\
\text { a station identifier, we use the sample's id as a station id. For stations with generic } \\
\text { names }(1,2,3, a, b, c \text {, etc.), we assign the station with the nomenclature: first author } \\
\text { last name_publication year_station number. }\end{array}$ \\
\hline lat_nad83 [Double] & $\begin{array}{l}\text { Latitude of sample location, if known (NAD83 datum). Sometimes, these coordinates } \\
\text { are imprecise because they were georeferenced from a figure or approximated } \\
\text { based on a location description. If so, it is noted in the description. }\end{array}$ \\
\hline long_nad83 [Double] & $\begin{array}{l}\text { Longitude of sample location, if known (NAD83 datum). Sometimes, these } \\
\text { coordinates are imprecise because they were georeferenced from a figure or } \\
\text { approximated based on a location description. If so, it is noted in the description. }\end{array}$ \\
\hline geologist [Text] & Name of the geologist who visited the station and collected the sample, if known. \\
\hline volcano [Text] & If the station that was visited was on a volcano, the volcano name is specified here. \\
\hline visitdate [Text] & Date the sample was collected. Sometimes only the year is known. \\
\hline stationdes [Text] & $\begin{array}{l}\text { Text description of the sample locality, if published. If no sample location was } \\
\text { published, a specific volcano name or geographic area may be entered. }\end{array}$ \\
\hline stationcom [Text] & Comments about the station. \\
\hline
\end{tabular}


Table 6. table_geodiva_samples_12072017 attributes and definitions.

\begin{tabular}{|c|c|}
\hline Attribute Field [data type] & Description \\
\hline OBJECTID [ObjectID] & ArcGIS-generated identifier. \\
\hline sampleid [Text] & $\begin{array}{l}\text { Alphanumeric descriptor of the sample. For samples with generic names }(1,2,3, a \text {, } \\
\text { b, c, etc.), we assign the sample name with the nomenclature: first author last } \\
\text { name_publication year_sample number. }\end{array}$ \\
\hline stationid [Text] & $\begin{array}{l}\text { The alphanumeric descriptor of the sample's station. For samples published without } \\
\text { a station identifier, we use the sample's id as a station id. For stations with generic } \\
\text { names }(1,2,3, a, b, c \text {, etc.), we assign the station with the nomenclature: first author } \\
\text { last name_publication year_station number. }\end{array}$ \\
\hline at_num [Text] & Alphanumeric ID assigned by the Alaska Tephra Lab. \\
\hline sourcevolc [Text] & If the tephra unit has a potential source vent. \\
\hline samp_date [Text] & Date the sample was collected. Sometimes only the year is known. \\
\hline samptype [Text] & samptype and sampletype2 describe the physical sample type. \\
\hline samptype2 [Text] & samptype and sampletype2 describe the physical sample type. \\
\hline age_epoch [Text] & Age epoch of the deposit/eruption (Pleistocene, Holocene, Alaska historical). \\
\hline color [Text] & Color of the sample, if provided. \\
\hline tephraname [Text] & Informal name of the tephra unit. \\
\hline alt_tephra [Text] & $\begin{array}{l}\text { Some tephra units have been given multiple names, this field provides an alternate } \\
\text { tephra name for those samples with multiple tephra unit names. }\end{array}$ \\
\hline name_comm [Text] & Comments on the tephra unit name. \\
\hline sampdes [Text] & Text description of the sample, if published. \\
\hline sampcom [Text] & Comments about the sample. \\
\hline
\end{tabular}

Table 7. table_references attributes and definitions.

\begin{tabular}{|l|l|}
\hline Attribute Field [data type] & Description \\
\hline OBJECTID [ObjectID] & ArcGIS-generated identifier. \\
\hline citationid [Double] & Unique numeric identifier that allows the reference to be linked to derived data. \\
\hline reference [Text] & Full reference. \\
\hline
\end{tabular}

Table 8. table_alaska_tephra_contours_figures attributes and definitions.

\begin{tabular}{|l|l|}
\hline Attribute Field [data type] & Description \\
\hline ATTACHMENTID [ObjectID] & ArcGIS-generated identifier. \\
\hline $\begin{array}{l}\text { REL_OBJECTID [Long } \\
\text { Integer] }\end{array}$ & ArcGIS-generated identifier. \\
\hline CONTENT_TYPE [Text] & Describes the attachment type (image/jpeg for all). \\
\hline ATT_NAME [Text] & Name of the file that is attached. \\
\hline DATA_SIZE [Long Integer] & Size of the attachment. \\
\hline DATA [Blob] & Data type. \\
\hline
\end{tabular}



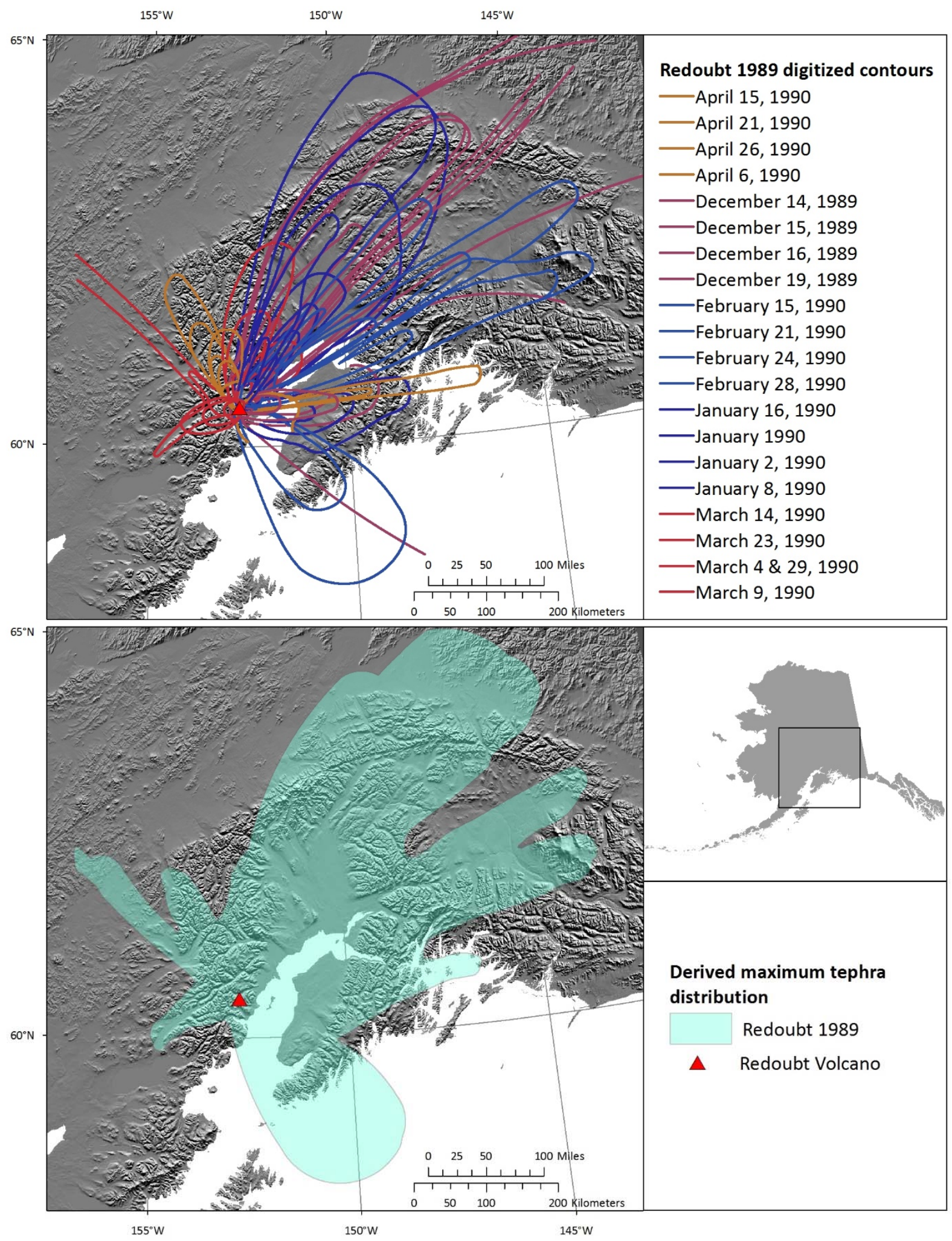

Figure 4. Redoubt 1989 tephra footprint polygon (lower) derived from digitized tephra contours (upper), from Scott and McGimsey (1994). 
Lastly, queried layer files for each tephra unit with a published distribution are also published here. Figure 3 presents examples of five such layer files, which exist for all 39 tephra units in the dataset (there are technically 40 distributions because an overall White River Ash distribution, including both the north and east lobes, is also included as the two deposits are often not distinguished in publications). Separate layer files exist for the Edgecumbe tephra set and Edgecumbe dacite tephra, although the Edgecumbe dacite tephra is considered a member of the tephra set (Begét and Motyka, 1998). For each tephra unit, the layer file contains queried data for the source volcano (if known), the individual contours pertaining to the deposit (if any), the derived maximum tephra distribution for the deposit, and stations with tephra samples of the deposit (if any). Contours are symbolized based on the reference that the contour was digitized from. To access an image of the original figure the contours were derived from, use the ArcMap "HTML Popup" tool to select the feature of interest in the map window. The volcanic vent locations are queried from either the historically active volcanoes (Cameron and Schaefer, 2016) or quaternary volcanic vents (Cameron and Nye, 2014) datasets depending on the vent.

\section{USING THE DATASET AND FUTURE GOALS}

We would eventually like to integrate this geospatial data with the Tephra Database module of the Alaska Volcano Observatory's Geologic Database of Information on Volcanoes in Alaska (GeoDIVA) and provide an online interface that will allow users to download specific tephra fall distribution data. Such a feature would aid researchers working at specific locations in Alaska by providing a rough prediction of ashfall units that may be encountered, and their approximate ages. In order to facilitate rapid release of the data, however, we are first publishing this geodatabase, which contains all of the data that is currently digitized.

A map document provides easy access to the queried layer files, which allows users to view data for specific tephra units listed in Table 1. As a base layer, the map document utilizes the Alaska Geospatial Council best data layer web mapping service (available at http://gis.dnr.alaska.gov/terrapixel/cubeserv/OIM BDL). The map document displays the "Alaska Tephra All" layer as a default, but by using the "List By Drawing Order" option of the Table Of Contents, users may select layers to display data relevant to specific deposits of interest. Users may access all data through the "Alaska Tephra All" layer in the map file or by accessing the individual feature classes and tables in the geodatabase. In ArcMap, the "Identify" and "HTML Popup" tools are useful for viewing metadata associated with individual features. We acknowledge that some users may wish to export subsets of data (e.g., only data on certain tephra units) from the geodatabase. Therefore, attribute field names have been limited to ten characters or less (except for Arc-generated geodatabase and attachment fields) to accommodate exporting shapefiles from the geodatabase. Note that features of the geodatabase, such as relationship classes, are not preserved when data are exported from the geodatabase as shapefiles. For example, the "alaska_tephra_contours" feature class has a relationship with a table that stores attachments of published figures with data that was digitized. When shapefiles are exported from the 
"alaska_tephra_contours" feature class, the relationship classes it has are not preserved and therefore the attachments of digitized figures will no longer be accessible to users. Likewise, relationship classes linking feature classes and tables to the reference table are not preserved. In addition to the reference table stored in the geodatabase, Appendix 1 contains a full list of references for all data cited in the geodatabase.

\section{ACKNOWLEDGEMENTS}

As a compilation of previously published data, this project is built on a foundation of work done by other scientists. The list of authors whose work contributed to this database would be too extensive to cite here, but each is credited in the reference table of the dataset. We would like to thank Patricia Gallagher (DGGS), Mike Hendricks (DGGS), and Kristi Wallace (USGS-AVO) for their review of this publication.

This project was funded through DGGS cooperative agreements with the USGS Volcano Hazards Program, grant numbers G16AC00054 and G16AC00165. The Alaska Volcano Observatory is a joint program of the U.S. Geological Survey, the Geophysical Institute of the University of Alaska Fairbanks, and the State of Alaska Division of Geological \& Geophysical Surveys. 


\section{REFERENCES CITED}

This is a list of references cited in this text document. See "Database References" list at the end of this document or reference tables in dataset for list of compiled data references.

Bacon, C.R., Neal, C.A., Miller, T.P., McGimsey, R.G., and Nye, C.J., 2014, Postglacial eruptive history, geochemistry, and recent seismicity of Aniakchak Volcano, Alaska: U.S. Geological Survey Professional Paper 1810, 74 p.

Bean, K.W., 1999, The Holocene eruptive history of Makushin Volcano, Alaska: Fairbanks, University of Alaska Fairbanks unpublished M.S. thesis, 130 p.

Begét, James, Mason, Owen, and Anderson, Patricia, 1992, Age, extent, and climatic significance of the c. 3400 BP Aniakchak tephra, western Alaska, USA: The Holocene, v. 2, no. 1, p. 5156.

Begét, J.E., Larsen, J.F., Neal, C.A., Nye, C.J., and Schaefer, J.R., 2005, Preliminary volcano-hazard assessment for Okmok Volcano, Umnak Island, Alaska: Alaska Division of Geological \& Geophysical Surveys Report of Investigation 2004-3, 32 p., 1 sheet, scale 1:150,000.

Begét, J.E., and Motyka, R.J., 1998, New dates on Late Pleistocene dacitic tephra from the Mount Edgecumbe volcanic field, southeastern Alaska: Quaternary Research, v. 49, no. 1, p. 123125.

Berger, G.W., Péwé, T.L., Westgate, J.A., and Preece, S.J., 1996, Age of Sheep Creek Tephra (Pleistocene) in central Alaska from thermoluminescence dating of bracketing loess: Quaternary Research, v. 45, no. 3, p. 263-270.

Cameron, C.E., Crass, S.W., Wallace, K.L., and Schaefer, J.R., 2016a, Geologic Database of Information on Volcanoes in Alaska (GeoDIVA), 2016 update (poster): Cities on Volcanoes 9 Conference, Puerto Varas, Chile, November 20-25, 2016.

Cameron, C.E., Mulliken, K.M., Schaefer, J.R., Wallace, K.L., and Crass, S.W., 2016b, Alaska Tephra Database (presentation): $9^{\text {th }}$ Biennial Workshop on Japan-Kamchatka-Alaska Subduction Processes, Fairbanks, Alaska, May 31-June 3, 2016.

Cameron, C.E., and Nye, C.J., 2014, Preliminary database of Quaternary vents in Alaska: Alaska Division of Geological \& Geophysical Surveys Miscellaneous Publication 153, 11 p.

Cameron, C.E., and Schaefer, J.R., 2016, Historically active volcanoes of Alaska: Alaska Division of Geological \& Geophysical Surveys Miscellaneous Publication 133 v. 2, 1 sheet, scale 1:3,000,000. http://doi.org/10.14509/20181

Cameron, C.E., Schaefer, J.R., Wallace, K.L., Snedigar, S.F., 2015, Alaska Tephra Database (presentation): The Geological Society of America 111 ${ }^{\text {th }}$ Annual Cordilleran Section Meeting, Anchorage, Alaska, May 11-13, 2015. 
Child, J.K., Begét, J.E., and Werner, Al, 1998, Three Holocene tephras identified in lacustrine sediment cores from the Wonder Lake area, Denali National Park and Preserve, Alaska, USA: Arctic and Alpine Research, v. 30, no. 1, p. 89-95.

Clague, J.J., Evans, S.G., Rampton, V.N., and Woodsworth, G.J., 1995, Improved age estimates for the White River and Bridge River tephras, western Canada: Canadian Journal of Earth Sciences, v. 32, p. 1172-1179.

Davies, L.J., Jensen, B.J., Froese, D.G., and Wallace, K.L., 2016, Late Pleistocene and Holocene tephrostratigraphy of interior Alaska and Yukon: Key beds and chronologies over the past 30,000 years: Quaternary Science Reviews, v. 146, p. 28-53.

de Fontaine, C.S., 2003, Late quaternary distal tephra in lacustrine sediments of the upper Cook Inlet, Alaska: Flagstaff, Northern Arizona University unpublished M.S. thesis, 111 p.

Dunning, Hilary, 2011, Extending the Applications of Tephrochronology in Northwestern North America: Alberta, University of Alberta M.S. thesis, 187 p.

Fierstein, Judy, 2007, Explosive eruptive record in the Katmai region, Alaska Peninsula: an overview: Bulletin of Volcanology, v. 69, no. 5, p. 469-509.

Fierstein, Judy, and Hildreth, Wes, 1992, The plinian eruptions of 1912 at Novarupta, Katmai National Park, Alaska: Bulletin of Volcanology, v. 54, no. 8, p. 646-684.

___ 2001, Preliminary volcano-hazard assessment for the Katmai volcanic cluster, Alaska: U.S. Geological Survey Open-File Report OF 00-0489, 50 p., 1 plate, scale not applicable.

-_-2008, Kaguyak dome field and its Holocene caldera, Alaska Peninsula: Journal of Volcanology and Geothermal Research, v. 177, no. 2, p. 340-366.

Froese, Daune, Westgate, John, Preece, Shari, and Storer, John, 2002, Age and significance of the late Pleistocene Dawson Tephra in eastern Beringia: Quaternary Science Reviews, v. 21, no. 20-22, p. 2137-2142.

Gardner, J.E., Burgisser, Alain, and Stelling, Pete, 2007, Eruption and deposition of the Fisher Tuff (Alaska): evidence for the evolution of pyroclastic flows: Journal of Geology, v. 115, p. 417435.

Jensen, B.J.L., 2007, Tephrochronology of Middle to Late Pleistocene Loess in Eastcentral Alaska: University of Alberta M.S. thesis, 120 p.

Jensen, B.J.L., Preece, S.J., Lamothe, Michel, Pearce, N.J.G., Froese, D.G., Westgate, J.A., Schaefer, Janet, and Begét, Jim, 2011, The variegated (VT) tephra: A new regional marker for middle to late marine isotope stage 5 across Yukon and Alaska: Quaternary International, v. 246, p. 312-323. 
Johnston, D.A., 1978, Volatiles, magma mixing, and the mechanism of eruption at Augustine volcano, Alaska: Seattle, University of Washington Ph.D. dissertation, 187 p., 20 plates, scale unknown.

Kienle, Juergen, and Swanson, S.E., 1983, Volcanism in the eastern Aleutian Arc: late Quaternary and Holocene centers, tectonic setting and petrology: Journal of Volcanology and Geothermal Research, v. 17, no. 1-4, p. 393-432.

Larsen, J.F., Neal, C.A., Schaefer, J.R., Kaufman, A.M., and Lu, Zhong, 2015, The 2008 phreatomagmatic eruption of Okmok Volcano, Aleutian Islands, Alaska: Chronology, deposits, and landform changes: Alaska Division of Geological \& Geophysical Surveys Report of Investigation 2015-2, 53 p.

Lerbekmo, J.F., 2008, The White River ash: largest Holocene plinian tephra: Canadian Journal of Earth Sciences, v. 45, no. 6, p. 693-700.

Mastin, L.G., Schwaiger, Hans, Schneider, D.J., Wallace, K.L., Schaefer, Janet, and Denlinger, R.P., 2013, Injection, transport, and deposition of tephra during event 5 at Redoubt Volcano, 23 March, 2009: Journal of Volcanology and Geothermal Research, v. 259, p. 201-213.

Moodie, D.W., Catchpole, A.J.W., and Abel, Kerry, 1992, Northern Athapaskan oral traditions and the White River volcano: Ethnohistory, v. 39, no. 2, p. 148-171.

Mullen, P.O., 2012, An archaeological test of the effects of the White River Ash eruptions: Arctic Anthropology, v. 49, p. 35-44.

Mulliken, K.M., 2016, Holocene volcanism and human occupation in the middle Susitna River Valley, Alaska: Fairbanks, University of Alaska Fairbanks M.A. thesis, 234 p.

Nayudu, Y.R., 1964, Volcanic ash deposits in the Gulf of Alaska and problems of correlation of deep-sea ash deposits: Marine Geology, v. 1, no. 3, p. 194-212.

Nicholson, R.S., 2003, The 1931 eruption of Aniakchak volcano, Alaska: Fairbanks, University of Alaska Fairbanks unpublished M.S. thesis, 270 p.

Preece, S.J., McGimsey, R.G., Westgate, J.A., Pearce, N.J.G., Hart, W.K., and Perkins, W.T., 2014, Chemical complexity and source of the White River Ash, Alaska and Yukon: Geosphere, v. 10, no.5., p. 1020-1042.

Preece, S.J., Pearce, N.J.G., Westgate, J.A., Froese, D.G., Jensen, B.J.L., and Perkins, W.T., 2011, Old Crow tephra across eastern Beringia: a single cataclysmic eruption at the close of Marine Isotope Stage 6: Quaternary Science Reviews, v. 30, p. 2069-2099.

Riehle, J.R., Champion, D.E., Brew, D.A., and Lanphere, M.A., 1992, Pyroclastic deposits of the Mount Edgecumbe volcanic field, Southeast Alaska: eruptions of a stratified magma chamber: Journal of Volcanology and Geothermal Research, v. 53, no. 1, p. 117-144. 
Riehle, J.R., Waitt, R.B., Meyer, C.E., and Calk, L.C., 1998, Age of formation of Kaguyak Caldera, eastern Aleutian Arc, Alaska, estimated by tephrochronology, in Gray, J.E. and Riehle, J.R., eds., Geologic studies in Alaska by the U.S. Geological Survey, 1996: U.S. Geological Survey Professional Paper PP 1595, p. 161-168.

Schaefer, J.R., 2015, Geospatial tephra distribution database of large volcanic eruption in Alaska (presentation): The Geological Society of America 111 ${ }^{\text {th }}$ Annual Cordilleran Section Meeting, Anchorage, Alaska, May 11-13, 2015.

Schaefer, J.R., and Wallace, K.L., 2012, Ash fall contour map of the 2009 eruption of Redoubt Volcano, Alaska: Digital shapefiles of contours and sample locations: Alaska Division of Geological \& Geophysical Surveys Miscellaneous Publication 143, 1 DVD.

Scott, W.E., and McGimsey, R.G., 1994, Character, mass, distribution, and origin of tephra-fall deposits of the 1989-1990 eruption of Redoubt volcano, south-central Alaska, in Miller, T.P. and Chouet, B.A., eds., The 1989-1990 eruptions of Redoubt Volcano, Alaska: Journal of Volcanology and Geothermal Research, v. 62, no. 1, p. 251-272.

Stelling, P.L., 2003, Volcanism on Unimak Island, Alaska, USA: a special focus on Shishaldin and Fisher volcanoes: Fairbanks, University of Alaska Fairbanks unpublished Ph.D. dissertation, 193 p. and one CD-ROM.

Stelling, Pete, Begét, J.E., Gardner, J.E., and Schaefer, J.R., 2014, Preliminary volcano-hazard assessment for Fisher volcano, Unimak Island, Alaska: Alaska Division of Geological \& Geophysical Surveys Report of Investigation 2014-5, 32 p., 1 sheet, scale 1:500,000.

Stelling, Pete, Gardner, J.E., and Begét, James, 2005, Eruptive history of Fisher Caldera, Alaska, USA: Journal of Volcanology and Geothermal Research, v. 139, no. 3-4, p. 163-183.

Stevens, D.S.P., 2012, Pre-1912 glacial and volcanic history near Windy Creek, Katmai National Park and Preserve, Alaska: National Park Service, Alaska Park Science v. 11, no. 1, p. 4651.

Unema, J.A., Ort, M.H., Larsen, J.F., Neal, C.A., and Schaefer, J.R., 2016, Water-magma interaction and plume processes in the 2008 Okmok eruption, Alaska: GSA Bulletin, 15 p.

Waitt, R.B., and Begét, J.E., 2009, Volcanic processes and geology of Augustine Volcano, Alaska: U.S. Geological Survey Professional Paper 1762, 78 p., 2 plates, scale 1:25,000.

Wallace, K.L., Coombs, M.L., Hayden, L.A., and Waythomas, C.F., 2014, Significance of a nearsource tephra-stratigraphic sequence to the eruptive history of Hayes Volcano, southcentral Alaska: U.S. Geological Survey Scientific Investigations Report 2014-5133, 32 p.

Wallace, K.L., Schaefer, J.R., and Coombs, M.L., 2013, Character, mass, distribution, and origin of tephra-fall deposits from the 2009 eruption of Redoubt Volcano, Alaska - Highlighting the 
significance of particle aggregation: Journal of Volcanology and Geothermal Research, v. 259, p. 145-169.

Waythomas, C.F., 2015, Geomorphic consequences of volcanic eruptions in Alaska: A review: Geomorphology, v. 246, p. 123-145.

Waythomas, C.F., Miller, T.P., and Mangan, M.T., 2006, Preliminary volcano hazard assessment for the Emmons Lake volcanic center, Alaska: U.S. Geological Survey Scientific Investigations Report 2006-5248, $41 \mathrm{p}$.

Waythomas, C.F., and Nye, C.J., 2002, Preliminary volcano-hazard assessment for Mount Spurr Volcano, Alaska: U.S. Geological Survey Open-File Report 2001-482, 40 p.

West, K.D., 2007, Resedimentation of the late Holocene White River ash, Yukon Territory, Canada, and Alaska, USA: Ottawa, Canada, Carleton University Ph.D. dissertation, 269 p.

West, K.D., and Donaldson, J.A., 2001, Resedimentation of the late Holocene White River tephra, Yukon Territory and Alaska: Yukon exploration and geology, p. 239-247.

Wilcox, R.E., 1959, Some effects of recent volcanic ash falls with special reference to Alaska, in Investigations of Alaskan volcanoes: U.S. Geological Survey Bulletin B 1028-N, p. 409-476, 5 sheets, scale unknown.

Wong, L.J., 2004, Physical volcanology of a sub-plinian and phreatomagmatic eruption at Okmok Volcano, Alaska: implications for explosive mafic volcanism: Fairbanks, University of Alaska Fairbanks unpublished M.S. thesis, 117 p.

Wong, L.J., and Larsen, J.F., 2010, The Middle Scoria sequence: A Holocene violent strombolian, subplinian, and phreatomagmatic eruption of Okmok volcano, Alaska: Bulletin of Volcanology, v. 72, p. 17-31. 


\section{APPENDIX 1: DATABASE REFERENCES CITED}

This is a comprehensive list of all sources of compiled data included in the geodatabase.

Addison, J.A., Begét, J.E., Ager, T.A., and Finney, B.P., 2010, Marine tephrochronology of the Mt. Edgecumbe Volcanic Field, Southeast Alaska, USA: Quaternary Research, v. 73, no. 2, p. 277-292.

Alaska Volcano Observatory, 1993, Mt. Spurr's 1992 eruptions: Eos, v. 74, no. 19, p. 217, 221-222.

Arce, G.N., 1983, Volcanic hazards from Makushin Volcano, northern Unalaska Island, Alaska: Fairbanks, University of Alaska Fairbanks unpublished M.S. thesis, 142 p., 2 sheets, scale unknown.

Avery, V. F., 1992, Petrogenetic study of dacite from the 1912 eruption Novarupta, Katmai National Park, Alaska: implications for magma storage locations: Fairbanks, University of Alaska Fairbanks unpublished M.S. thesis, 177 p.

Axford, Yarrow, and Kaufman, D.S., 2004, Late glacial and Holocene glacier and vegetation fluctuations at Little Swift Lake, Southwestern Alaska, U.S.A.: Arctic, Antarctic, and Alpine Research, v. 36, no. 2, p. 139-146.

Bacon, C.R., Neal, C.A., Miller, T.P., McGimsey, R.G., and Nye, C.J., 2014, Postglacial eruptive history, geochemistry, and recent seismicity of Aniakchak Volcano, Alaska: U.S. Geological Survey Professional Paper 1810, 74 p.

Bean, K.W., 1999, The Holocene eruptive history of Makushin Volcano, Alaska: Fairbanks, University of Alaska Fairbanks unpublished M.S. thesis, 130 p.

Begét, James, Edwards, Mary, Hopkins, David, Keskinen, Mary, and Kukla, George, 1991, Old Crow Tephra found at the Palisades of the Yukon, Alaska: Quaternary Research, v. 35, no. 2, p. 291-297.

Begét, James, Mason, Owen, and Anderson, Patricia, 1992, Age, extent, and climatic significance of the c. 3400 BP Aniakchak tephra, western Alaska, USA: The Holocene, v. 2, no. 1, p. 5156.

Begét, J.E., 1994, Tephrochronology, lichenometry and radiocarbon dating at Gulkana Glacier, central Alaska Range, USA: The Holocene, v. 4, no. 3, p. 307-313.

Begét, J.E., Hopkins, D.M., and Charron, S.D., 1996, The largest known maars on earth, Seward Peninsula, northwest Alaska: Arctic, v. 49, no. 1, p. 62-69.

Begét, J.E., and Keskinen, Mary, 1991, The Stampede Tephra: a middle Pleistocene marker bed in glacial and eolian deposits of central Alaska: Canadian Journal of Earth Sciences, v. 28, no. 7, p. 991-1002. 
Begét, J.E., and Keskinen, M.J., 2003, Trace-element geochemistry of individual glass shards of the Old Crow Tephra and the age of the Delta glaciation, central Alaska, in Westgate, J.A., ed., Special issue dedicated to Troy Péwé: Quaternary Research, v. 60, no. 1, p. 63-69.

Begét, J.E., and Motyka, R.J., 1998, New dates on Late Pleistocene dacitic tephra from the Mount Edgecumbe volcanic field, southeastern Alaska: Quaternary Research, v. 49, no. 1, p. 123125.

Begét, J.E., Reger, R.D., Pinney, DeAnne, Gillispie, Tom, and Campbell, Kathy, 1991, Correlation of the Holocene Jarvis Creek, Tangle Lakes, Cantwell, and Hayes tephras in south-central and central Alaska: Quaternary Research, v. 35, no. 2, p. 174-189.

Begét, J.E., Stihler, S.D., and Stone, D.B., 1994, A 500-year-long record of tephra falls from Redoubt volcano and other volcanoes in upper Cook Inlet, Alaska, in Miller, T.P. and Chouet, B.A., eds., The 1989-1990 eruptions of Redoubt Volcano, Alaska: Journal of Volcanology and Geothermal Research, v. 62, no. 1-4, p. 55-67.

Berger, G.W., 2003, Luminescence chronology of late Pleistocene loess-Paleosol and tephra sequences near Fairbanks, Alaska, in Westgate, J.A., ed., Special issue dedicated to Troy Péwé: Quaternary Research, v. 60, no. 1, p. 70-83.

Berger, G.W., Péwé, T.L., Westgate, J.A., and Preece, S.J., 1996, Age of Sheep Creek Tephra (Pleistocene) in central Alaska from thermoluminescence dating of bracketing loess: Quaternary Research, v. 45, no. 3, p. 263-270.

Bindeman, I.N., Fournelle, J.H., and Valley, J.W., 2001, Low-delta (super 18) O tephra from a compositionally zoned magma body: Fisher Caldera, Unimak Island, Aleutians: Journal of Volcanology and Geothermal Research, v. 111, no. 1-4, p. 35-53.

Blackford, J.J., Payne, R.J., Heggen, M.P., de la Riva Caballero, A., and van der Plicht, J., 2014, Age and impacts of the caldera-forming Aniakchak II eruption in western Alaska: Quaternary Research, v. 82, p. 85-95.

Blong, J.C., 2016, Prehistoric Landscape Use in the Central Alaska Range: College Station, Texas A \& M University $\mathrm{PhD}$ dissertation, $421 \mathrm{p}$.

Bostock, H.S., 1952, Geology of northwest Shakwak Valley, Yukon Territory: Geological Survey of Canada, Memoir 267.

Bowers, P.M., 1979, The Cantwell ash bed, a Holocene tephra in the central Alaska Range, in Short notes on Alaskan geology: Alaska Division of Geological \& Geophysical Surveys Geologic Report GR 0061, p. 19-24.

Briggs, N.D., and Westgate, J.A., 1978, A contribution to the Pleistocene geochronology of Alaska and the Yukon Territory: fission-track age of distal tephra units, in Short papers of the 
fourth international conference, geochronology, cosmochronology, isotope geology, 1978: U.S. Geological Survey Open-File Report OF 78-0701, p. 49-52.

Byers, F.M., Jr., 1959, Geology of Umnak and Bogoslof Islands, Aleutian Islands, Alaska, in Investigations of Alaskan volcanoes: U.S. Geological Survey Bulletin B 1028-L, p. 267-369, 5 sheets, scale 1 at 1:63,360, 1 at 1:96,000, and 1 at 1:300,000.

Byers, F.M., Jr., 1961, Petrology of three volcanic suites, Umnak and Bogoslof Islands, Aleutian Islands, Alaska: Geological Society of America Bulletin, v. 72, no. 1, p. 93-128.

Capps, S.R., 1915, An ancient volcanic eruption in the upper Yukon basin, in Shorter contributions to general geology: U.S. Geological Survey Professional Paper PP 0095-D, p. 59-64.

Carson, E.C., 1998, Holocene tephrochronology of the Cold Bay area, Southwest Alaska Peninsula: Madison, University of Wisconsin-Madison unpublished M.S. thesis, 178 p.

Carson, E.C., Fournelle, J.H., Miller, T.P., and Mickelson, D.M., 2002, Holocene tephrochronology of the Cold Bay area, southwest Alaska Peninsula: Quaternary Science Reviews, v. 21, no. 20-22, p. 2213-2228.

Casadevall, T.J., 1994, The 1989-1990 eruption of Redoubt Volcano, Alaska: impacts on aircraft operations, in Miller, T.P. and Chouet, B.A., eds., The 1989-1990 eruptions of Redoubt Volcano, Alaska: Journal of Volcanology and Geothermal Research, v. 62, no. 1, p. 301316.

Child, J.K., Begét, J.E., and Werner, Al, 1998, Three Holocene tephras identified in lacustrine sediment cores from the Wonder Lake area, Denali National Park and Preserve, Alaska, USA: Arctic and Alpine Research, v. 30, no. 1, p. 89-95.

Clague, J.J., Evans, S.G., Rampton, V.N., and Woodsworth, G.J., 1995, Improved age estimates for the White River and Bridge River tephras, western Canada: Canadian Journal of Earth Sciences, v. 32, p. 1172-1179.

Coats, R.R., 1959, Geologic reconnaissance of Semisopochnoi Island, western Aleutian Islands, Alaska, in Investigations of Alaskan volcanoes: U.S. Geological Survey Bulletin B 1028-O, p. 477-519, 1 sheet, scale 1:25,000.

Combellick, R.A., and Pinney, D.S., 1995, Radiocarbon age of probable Hayes Tephra, Kenai Peninsula, Alaska, in Combellick, R.A., and Tannian, Fran, eds., Short notes on Alaska Geology 1995: Alaska Division of Geological \& Geophysical Surveys Professional Report 117A, p. 1-9.

Coombs, M.L., 2001, Experimental and petrologic constraints on magma movement, storage, and interactions at two volcanoes in Katmai National Park, Alaska: Fairbanks, University of Alaska Fairbanks unpublished Ph.D. dissertation, 214 p. 
Coombs, M.L., Eichelberger, J.C., and Rutherford, M.J., 2000, Magma storage and mixing conditions for the 1953-1974 eruptions of Southwest Trident volcano, Katmai National Park, Alaska: Contributions to Mineralogy and Petrology, v. 140, no. 1, p. 99-118, 1 sheet, scale unknown.

Coombs, M.L., McGimsey, R.G., and Browne, B.L., 2012, Geologic map of Mount Gareloi, Gareloi Island, Alaska: U.S. Geological Survey Scientific Investigations Map 3145, 18 p., 1 sheet, scale 1:24,000.

Coombs, M.L., Sisson, T.W., Bleick, H.A., Henton, S.M., Nye, C.J., Payne, A.L., Cameron, C.E., Larsen, J.F., Wallace, K.L., and Bull, K.F., 2013, Andesites of the 2009 eruption of Redoubt Volcano, Alaska: Journal of Volcanology and Geothermal Research, v. 259, p. 349-372.

Coulter, S.E., Pilcher, J.R., Plunkett, Gill, Baillie, Mike, Hall, V.A., Steffensen, J.P., Vinther, B.M., Clausen, H.B., and Johnsen, S.J., 2012, Holocene tephras highlight complexity of volcanic signals in Greenland ice cores: Journal of Geophysical Research, v. 117, 11 p.

Curtis, G.H., 1968, The stratigraphy of the ejecta from the 1912 eruption of Mount Katmai and Novarupta, Alaska, in Coats, R.R., Hay, R.L., and Anderson, C.A., eds., Studies in volcanology: Geological Society of America Memoir MWR 0116, p. 153-210.

Davis, K.M., 2006, Volcanic, tectonic, and tsunamigenic events recorded in peats near Millers Landing, Homer, Alaska: Fairbanks, University of Alaska, Fairbanks unpublished M.S. thesis, $135 \mathrm{p}$.

Davies, L.J., Jensen, B.J., Froese, D.G., and Wallace, K.L., 2016, Late Pleistocene and Holocene tephrostratigraphy of interior Alaska and Yukon: Key beds and chronologies over the past 30,000 years: Quaternary Science Reviews, v. 146, p. 28-53.

de Fontaine, C.S., 2003, Late quaternary distal tephra in lacustrine sediments of the upper Cook Inlet, Alaska: Flagstaff, Northern Arizona University unpublished M.S. thesis, 111 p.

de Fontaine, C.S., Kaufman, D.S., Anderson, R.S., Werner, Al, Waythomas, C.F., and Brown, T.A., 2007, Late Quaternary distal tephra-fall deposits in lacustrine sediments, Kenai Peninsula, Alaska: Quaternary Research, v. 68, p. 64-78.

Demuro, M., Roberts, R.G., Froese, D.G., Arnold, L.J., Brock, F., and Ramsey, C.B., 2008, Optically stimulated luminescence dating of single and multiple grains of quartz from perennially frozen loess in western Yukon Territory, Canada: comparison with radiocarbon chronologies for the late Pleistocene Dawson tephra: Quaternary Geochronology, v. 3, no. 4, p. 346-364.

Denton, J.S., Pearce, N.J.G., 2008, Comment on "A synchronized dating of three Greenland ice cores throughout the Holocene" by B.M. Vinther et al.: no Minoan tephra in the 1642 B.C. layer of the GRIP ice core: Journal of Geophysical Research, v. 113, 7 p., D04303. 
DeRuwe, A.D., 2008, An 18,700 year record of tephra-fall frequency as recorded in peat cores recovered from the Kenai Peninsula, Alaska: Anchorage, Alaska Pacific University M.S. thesis, $82 \mathrm{p}$.

Detterman, R.L., and Reed, B.L., 1980, Stratigraphy, structure, and economic geology of the Iliamna Quadrangle, Alaska: U.S. Geological Survey Bulletin B 1368-B, 86 p., 1 sheet, scale $1: 250,000$.

Dilley, T.E., 1988, Holocene tephra stratigraphy and pedogenesis in the middle Susitna River valley, Alaska: Fairbanks, University of Alaska, Fairbanks unpublished M.S. thesis, 97 p.

Dochat, T.M., 1997, Quaternary stratigraphy and geomorphology of the Cold Bay region of the Alaska Peninsula: a basis for paleoenvironmental reconstruction (glacial deposits): Madison, University of Wisconsin unpublished Ph.D. dissertation, 330 p.

Donaldson, J.A., Guerstein, P.G., and Mueller, Wulf, 1996, Facies analysis of a pumiceous terrace beside Klutlan Glacier, Yukon Territory: Canadian Journal of Earth Sciences, v. 33, no. 9, p. $1233-1242$.

Downes, Hilary, 1985, Evidence for magma heterogeneity in the White River Ash (Yukon Territory): Canadian Journal of Earth Sciences, v. 22, no. 6, p. 929-934.

Dreher, S.T., 2002, The physical volcanology and petrology of the 3400 YBP caldera-forming eruption of Aniakchak Volcano, Alaska: Fairbanks, University of Alaska Fairbanks unpublished Ph.D. dissertation, $174 \mathrm{p}$.

Dunning, Hilary, 2011, Extending the Applications of Tephrochronology in Northwestern North America: Alberta, University of Alberta M.S. thesis, $187 \mathrm{p}$.

Edwards, David, 1991, Tephrochronology in the Kluane region of the Yukon Territory, Canada: The Edinburgh Geologist, v. 25, p. 15-24.

Edsall, D.W., 1975, Submarine geology of volcanic ash deposits: stratigraphy, age, and magmatic composition of Hawaiian and Aleutian tephra: Eocene to recent: New York, Columbia University unpublished Ph.D. dissertation, $264 \mathrm{p}$.

Elias, S.E., Hamilton, T.D., Edwards, M.E., Begét, J.E., Krumhardt, A.P., and Lavoie, Claude., 1999, Late Pleistocene environments of the western Noatak basin, northwestern Alaska: Geological Society of America Bulletin, v. 111, p. 769-789.

Federman, A.N., 1984, Correlation and petrological interpretation of abyssal and terrestrial tephra layers (Novarupta, Mazama, St. Helens, Washington): Corvallis, Oregon State University Ph.D. dissertation, $241 \mathrm{p}$.

Federman, A.N., and Scheidegger, K.F., 1980, Chemical composition of air fall tephra from the 1912 eruption of Katmai Volcano, Alaska [abs.]: Eos, v. 61, no. 6, p. 65-66. 
Federman, A.N., and Scheidegger, K.F., 1984, Compositional heterogeneity of distal tephra deposits from the 1912 eruption of Novarupta, Alaska: Journal of Volcanology and Geothermal Research, v. 21, no. 3-4, p. 233-254.

Feeley, T.C., and Winer, G.S., 1999, Evidence for fractionation of Quaternary basalts on St. Paul Island, Alaska, with implications for the development of shallow magma chambers beneath Bering Sea volcanoes: Lithos, v. 46, no. 4, p. 661-676.

Feinberg, A.E., 2000, Evidence of Holocene glacial activity from the Ahklun Mountains, southwestern Alaska: south Hadley, Mount Holyoke College unpublished B.A. thesis, 83 p.

Fenner, C.N., 1926, The Katmai magmatic province: Journal of Geology, v. 34, no. 7, p. 673-772.

Fierstein, Judy, 2007, Explosive eruptive record in the Katmai region, Alaska Peninsula: an overview: Bulletin of Volcanology, v. 69, no. 5, p. 469-509.

Fierstein, Judy, and Hildreth, Wes, 1992, The plinian eruptions of 1912 at Novarupta, Katmai National Park, Alaska: Bulletin of Volcanology, v. 54, no. 8, p. 646-684.

___ 2001, Preliminary volcano-hazard assessment for the Katmai volcanic cluster, Alaska: U.S. Geological Survey Open-File Report OF 00-0489, 50 p., 1 plate, scale not applicable.

- - - 2008, Kaguyak dome field and its Holocene caldera, Alaska Peninsula: Journal of Volcanology and Geothermal Research, v. 177, no. 2, p. 340-366.

Fierstein, J., Houghton, B.F., Wilson, C.J.N., and Hildreth, W., 1997, Complexities of plinian fall deposition at vent: an example from the 1912 Novarupta eruption (Alaska): Journal of Volcanology and Geothermal Research, v. 76, no. 3-4, p. 215-227.

Finney, B.M., 2004, Magmatic differentiation at an island-arc caldera: a stratigraphically constrained multi-isotope study of Okmok Volcano, Aleutian Islands, Alaska: Bristol, University of Bristol Ph.D. dissertation, $296 \mathrm{p}$.

Fontana, M.R., 1988, Holocene tephrochronology of the Matanuska Valley, Alaska: Fairbanks, University of Alaska Fairbanks M.S. thesis, 99 p.

Fournelle, J.H., 1988, Geology and petrology of Shishaldin volcano, Unimak Island, Aleutian Arc, Alaska: Baltimore, Johns Hopkins University Ph.D. dissertation, 507 p., 2 plates, scale unknown.

Fournelle, John, and Marsh, B.D., 1991, Shishaldin Volcano: Aleutian high-alumina basalts and the question of plagioclase accumulation: Geology, v. 19, no. 3, p. 234-237.

Froese, D.G., Smith, D.G., Westgate, J.A., Ager, T.A., Preece, S.J., Sandhu, Amanjit, Enkin, R.J., and Weber, Florence, 2003, Recurring middle Pleistocene outburst floods in east-central Alaska: Quaternary Research, v. 60, no. 1, p. 50-62. 
Froese, D.G, Westgate, J.A., and Alloway, B.V., eds., 2005, Field trip guide for the International Field Conference and Workshop on Tephrochronology and Volcanism: Institute of Geological and Nuclear Sciences Science Report 2005/26, Dawson City, Yukon Territory, Canada, July 31-August 8, 2005, 132 p.

Froese, Duane, Westgate, John, Preece, Shari, and Storer, John, 2002, Age and significance of the late Pleistocene Dawson Tephra in eastern Beringia: Quaternary Science Reviews, v. 21, no. 20-22, p. 2137-2142.

Froese, D.G., Zazula, G.D., and Reyes, A.V., 2006, Seasonality of the late Pleistocene Dawson tephra and exceptional preservation of a buried riparian surface in central Yukon Territory, Canada: Quaternary Science Reviews, v. 25, p. 1542-1551.

Froese, D.G., Zazula, G.D., Westgate, J.A., Preece, S.J., Sanborn, P.T., Reyes, A.V., Pearce, N.J.G., 2009, The Klondike goldfields and Pleistocene environments of Beringia: GSA Today, v. 19 , no. 4 , p. $4-10$.

Gardner, J.E., Burgisser, Alain, and Stelling, Pete, 2007, Eruption and deposition of the Fisher Tuff (Alaska): evidence for the evolution of pyroclastic flows: Journal of Geology, v. 115, p. 417435.

Gardner, C.A., Cashman, K.V., and Neal, C.A., 1998, Tephra-fall deposits from the 1992 eruption of Crater Peak, Alaska: implications of clast textures for eruptive processes: Bulletin of Volcanology, v. 59, no. 8, p. 537-555.

Gerlach, T.M., Westrich, H.R., Casadevall, T.J., and Finnegan, D.L., 1994, Vapor saturation and accumulation in magmas of the 1989-1990 eruption of Redoubt Volcano, Alaska, in Miller, T.P. and Chouet, B.A., eds., The 1989-1990 eruptions of Redoubt Volcano, Alaska: Journal of Volcanology and Geothermal Research, v. 62, no. 1-4, p. 317-337.

Graham, R.W., Belmecheri, Soumaya, Choy, Kyungcheol, Culleton, B.J., Davies, L.J., Froese, Duane, Heintzman, P.D., Hritz, Carrie, Kapp, J.D., Newsom, L.A., Rawcliffe, Ruth, Saulnier-Talbot, Emilie, Shapiro, Beth, Wang, Yue, Williams, J.W., and Wooller, M.J., 2016, Timing and causes of mid-Holocene mammoth extinction on St. Paul Island, Alaska: Proceedings of the National Academy of Sciences, v. 113, no. 33, p. 9310-9314.

Grey, D.M., 2003, Post-caldera eruptions at Okmok volcano, Umnak Island, Alaska, with emphasis on recent eruptions from Cone A: Fairbanks, University of Alaska Fairbanks unpublished M.S. thesis, $135 \mathrm{p}$.

Griggs, R.F., 1922, The Valley of Ten Thousand Smokes: Washington, DC, National Geographic Society, 340 p., 3 sheets, scale unknown.

Griggs, R.F., 1919, The beginnings of revegetation in Katmai Valley, in Scientific Results of the Katmai Expedition of the National Geographic Society Paper: The Ohio Journal of Science, v. 19, p. $318-342$. 
Hammer, C.U., Kurat, Gero, Hoppe, Peter, Grum, Walter, and Clausen, H.B., 2003, Thera eruption date 1645 BC confirmed by new ice core data?: paper presented at SCIEM 2000EuroConference, Vienna.

Hammer, J.E., Rutherford, M.J., and Hildreth, Wes, 2002, Magma storage prior to the 1912 eruption at Novarupta, Alaska: Contributions to Mineralogy and Petrology, v. 144, no. 2, p. $144-162$.

Hanson, L.W., 1965, Size distribution of the White River Ash, Yukon Territory: Alberta, Canada, University of Alberta M.S. thesis, 59 p.

Harbin, M.L., Swanson, S.E., Nye, C.J., and Miller, T.P., 1995, Preliminary petrology and chemistry of proximal eruptive products: 1992 eruptions of Crater Peak, Mount Spurr volcano, Alaska, in Keith, T.E.C., ed., The 1992 eruptions of Crater Peak Vent, Mount Spurr volcano, Alaska: U.S. Geological Survey Bulletin B 2139, p. 139-148.

Hildreth, Wes, 1983, The compositionally zoned eruption of 1912 in the Valley of Ten Thousand Smokes, Katmai National Park, Alaska: Journal of Volcanology and Geothermal Research, v. 18 , no. $1-4$, p. $1-56$.

Hildreth, Wes, and Fierstein, Judy, 2012a, The Novarupta-Katmai eruption of 1912: Largest eruption of the twentieth century: Centennial perspectives: U.S. Geological Survey Professional Paper 1791, 259 p.

- - 2012b, Eruptive history of Mount Katmai, Alaska: Geosphere, v. 8, no. 6, p. 1527-1567.

Hildreth, Wes, Fierstein, Judy, Lanphere, M.A., and Siems, D.F., 2001, Snowy Mountain: A pair of small andesite-dacite stratovolcanoes in Katmai National Park, in Gough, L.P. and Wilson, F.H., eds., Geologic studies in Alaska by the U.S. Geological Survey, 1999: U.S. Geological Survey Professional Paper PP 1633, p. 13-34.

- - 2002, Mount Griggs: A compositionally distinctive Quaternary stratovolcano behind the main volcanic line in Katmai National Park, in Wilson, F.H. and Galloway, J.P., eds., Studies by the U.S. Geological Survey in Alaska, 2000: U.S. Geological Survey Professional Paper PP 1662, p. 87-112.

- - 2003, Trident Volcano: four contiguous stratocones adjacent to Katmai Pass, Alaska Peninsula, in Galloway, J.P., ed., Studies by the U.S. Geological Survey in Alaska, 2001: U.S. Geological Survey Professional Paper PP 1678, p. 153-180.

Hogan, L.G., Scheidegger, K.F., Kulm, L.D., Dymond, J., and Mikkelsen, N., 1978, Biostratigraphic and tectonic implications of $40 \mathrm{Ar}-39 \mathrm{Ar}$ dates of ash layers from the Northeast Gulf of Alaska: Geological Society of America Bulletin, v. 89, no. 8, p. 1259-1264. 
Houghton, B.F., Wilson, C.J.N., Fierstein, J., and Hildreth, W.., 2004, Complex proximal deposition during the Plinian eruptions of 1912 at Novarupta, Alaska: Bulletin of Volcanology, v. 66, no. 2, p. 95-113.

Hughes, O.L., Rampton, V.N., and Rutter, N.W., 1972, Quaternary geology and geomorphology, southern and central Yukon (northern Canada): 24th International Geological Congress (Montreal), Guidebook, Field Excursion A11.

Jackson Jr., L.E., Froese, D.G., Telka, A.M., Westgate, J.A., Preece, Shari, Storer, J.E., and Huscroft, C.A., 2002, Late Cenozoic geology, Ancient Pacific Margin NATMAP Project, report 5: paleoecology and proxy climatic change records, south Klondike placer region, Yukon Territory: Geological Survey of Canada, Currrent Research, 2002-A2, 16 p.

Jennings, Anne, Thordarson, Thorvaldur, Zalzal, Kate, Stoner, Joseph, Hayward, Christopher, Geirsdottir, Aslaug, and Miller, Gifford, 2014, Holocene tephra from Iceland and Alaska in SE Greenland shelf sediments: Geological Society of London Special Publication Marine Tephrochronology, v. 398, p. 157-193.

Jensen, B.J.L., 2007, Tephrochronology of Middle to Late Pleistocene Loess in Eastcentral Alaska: University of Alberta M.S. thesis, $120 \mathrm{p}$.

Jensen, B.J.L., Evans, M.E., Froese, D.G., and Kravchinsky, V.A., 2016, 150,000 years of loess accumulation in central Alaska: Quaternary Science Reviews, v. 135, p. 1-23.

Jensen, B.J.L., Froese, D.L., Preece, S.J., Westgate, J.A., and Stachel, Thomas, 2008, An extensive middle to late Pleistocene tephrochronologic record from east-central Alaska: Quaternary Science Reviews, v. 27, p. 411-427.

Jensen, B.J.L., Preece, S.J., Lamothe, Michel, Pearce, N.J.G., Froese, D.G., Westgate, J.A., Schaefer, Janet, and Begét, Jim, 2011, The variegated (VT) tephra: A new regional marker for middle to late marine isotope stage 5 across Yukon and Alaska: Quaternary International, v. 246, p. 312-323.

Jensen, B.J.L., Pyne-O'Donnell, Sean, Plunkett, Gill, Froese, D.G., Hughes, P.D.M., Sigl, Michael, McConnell, J.R., Amesbury, M.J., Blackwell, P.J., van den Bogaard, Christel, Buck, C.E., Charman, D.J., Clague, J.J., Hall, V.A., Koch, Johannes, Mackay, Helen, Mallon, Gunnar, McColl, Lynsey, and Pilcher, J.R., 2014, Transatlantic distribution of the Alaskan White River Ash: Geology, v. 42 , no. 10, p. $875-878$.

Jensen, B.J.L., Reyes, A.V., Froese, D.G., and Stone, D.B., 2013, The Palisades is a key reference site for the middle Pleistocene of eastern Beringia: new evidence from paleomagnetics and regional tephrostratigraphy: Quaternary Science Reviews, v. 63, p. 91-108.

Jicha, B.R., Coombs, M.L., Calvert, A.T., and Singer, B.S., 2012, Geology and 40Ar/39Ar geochronology of the medium- to high-K Tanaga volcanic cluster, western Aleutians: Geological Society of America Bulletin, v. 124, no. 5/6, p. 842-856. 
Johnston, D.A., 1978, Volatiles, magma mixing, and the mechanism of eruption at Augustine volcano, Alaska: Seattle, University of Washington Ph.D. dissertation, 187 p., 20 plates, scale unknown.

Kathan, Kasey, 2006, Late Holocene climate fluctuations at Cascade Lake, northeastern Ahklun Mountains, southwestern Alaska: Flagstaff, Northern Arizona University M.S. thesis, 112 p.

Kaufman, D.S., Hu, F.S., Briner, J.P., Werner, Al, Finney, B.P., and Gregory-Eaves, Irene, 2003, A 33,000 year record of environmental change from Arolik Lake, Ahklun Mountains, Alaska: Journal of Paleolimnology, v. 30, p. 343-362.

Kaufman, D.S., Jensen, B.J.L., Reyes, A.V., Schiff, C.J., Froese, D.G., and Pearce, N.J.G., 2012, Late Quaternary tephrostratigraphy, Ahklun Mountains, SW Alaska: Journal of Quaternary Science, v. 27, no. 4, p. 344-359.

Kaufman, D.S., Manley, W.F., Wolfe, A.P., Hu, F.S., Preece, S.J., Westgate, J.A., and Forman, S.L., 2001, The last interglacial to glacial transition, Togiak Bay, southwestern Alaska: Quaternary Research, v. 55, no. 2, p. 190-202.

Kaufman., D.S., and Stilwell, K.B., 1997, Preliminary evaluation of emergent postglacial shorelines, Naknek and Iliamna lakes, southwestern Alaska, in Dumoulin, J.A., and Gray, J.E., eds., Geologic Studies in Alaska by the U.S. Geological Survey, 1995: U.S. Geological Survey Professional Paper 1574, p. 73-81.

Kay, S.M., and Kay, R.W., 1994, Aleutian magmas in space and time, in Plafker, George and Berg, H.C., eds., The Geology of Alaska, Geological Society of America: The Geology of North America series v. G-1, p. 687-722.

Keith, T.E.C., ed., 1995, The 1992 eruptions of Crater Peak Vent, Mount Spurr volcano, Alaska: U.S. Geological Survey Bulletin B 2139, 220 p.

Kienle, Juergen, 1976, Search for shallow magma accumulations at Augustine Volcano: University of Alaska Fairbanks Interim Progress Report and Proposal for No Fund Extension, 15 p.

Kienle, Juergen, and Forbes, R.B., 1977, Augustine - evolution of a volcano: University of Alaska Fairbanks Geophysical Institute Annual Report AR 1975-76, p. 26-48.

Kienle, Juergen, Kyle, P.R., Self, Stephen, Motyka, R.J., and Lorenz, Volker, 1980, Ukinrek Maars, Alaska: I, April 1977 eruption sequence, petrology and tectonic setting: Journal of Volcanology and Geothermal Research, v. 7, no. 1, p. 11-37.

Kienle, Juergen, Motyka, R.J., Lalla, D.J., Estes, S.A., and Huot, J.P., 1978, Formation of two maars behind the Aleutian volcanic arc, Alaska Peninsula, April 1977, preliminary results: field reconnaissance, geochemistry and seismicity: University of Alaska Fairbanks Geophysical Institute Report UAG-R 257, 26 p. 
Kienle, Juergen, and Swanson, S.E., 1983, Volcanism in the eastern Aleutian Arc: late Quaternary and Holocene centers, tectonic setting and petrology: Journal of Volcanology and Geothermal Research, v. 17, no. 1-4, p. 393-432.

Kiriyanov, V.Y., and Miller, T.P., 1997, Volcanic ashes of Adak Island, Aleutian Islands, Alaska: Volcanology and Seismology, v. 19, no. 1, p. 52-77.

Krawiec, A.C.L, 2013, Holocene tephrochronology and storminess inferred from two lakes on Adak Island, Alaska: Flagstaff, Northern Arizona University Ph.D. dissertation, 109 p.

Krawiec, A.C., Kaufman, D.S., and Vaillencourt, D.A., 2013, Age models and tephrostratigraphy from two lakes on Adak Island, Alaska: Quaternary Geochronology, v. 18, p .41-53.

Kunk, M.J., 1995, 40Ar/39Ar age-spectrum data for hornblende, plagioclase and biotite from tephras collected at Dan Creek and McCallum Creek, Alaska and in the Klondike placer district near Dawson, Yukon Territory, Canada: U.S. Geological Survey Open-File Report OF 95-0217-A, 52 p.

Lakeman, T.R., Clague, J.J., Menounos, Brian, Osborn, G.D., Jensen, B.J.L., Froese, D.G., 2008, Holocene tephras in lake cores from northern British Columbia, Canada: Canadian Journal of Earth Science, v. 45, p. 935-947.

Larsen, J.F., Neal, C.A., Schaefer, J.R., Kaufman, A.M., and Lu, Zhong, 2015, The 2008 phreatomagmatic eruption of Okmok Volcano, Aleutian Islands, Alaska: Chronology, deposits, and landform changes: Alaska Division of Geological \& Geophysical Surveys Report of Investigation 2015-2, 53 p.

Larsen, J.F., Nye, C.J., Coombs, M.L., Tilman, Mariah, Izbekov, Pavel, and Cameron, Cheryl, 2010, Petrology and geochemistry of the 2006 eruption of Augustine Volcano, chapter 15 in Power, J.A., Coombs, M.L., and Freymueller, J.T., eds., The 2006 eruption of Augustine Volcano, Alaska: U.S. Geological Survey Professional Paper 1769, p. 335-382 and spreadsheets.

Larsen, J.F., Sliwinski, M.G., Nye, Christopher, Cameron, Cheryl, and Schaefer, J.R., 2013, The 2008 eruption of Okmok Volcano, Alaska: Petrological and geochemical constraints on the subsurface magma plumbing system: Journal of Volcanology and Geothermal Research, v. 264 , p. 85-106.

Lemke, K.J., 2000, Holocene tephrostratigraphy, southern Kenai Peninsula, Lower Cook Inlet, Alaska: Logan, Utah State University unpublished M.S. thesis, 96 p.

Lenz, Josefine, Grosse, Guido, Jones, B.M., Anthony, K.M.W., Bobrov, Anatoly, Wulf, Sabine and Wetterich, Sebastian, 2016, Mid-Wisconsin to Holocene Permafrost and Landscape Dynamics based on a Drained Lake Basin Core from the Northern Seward Peninsula, Northwest Alaska: Permafrost and Periglacial Processes, v. 27, no. 1, p. 56-75. 
Lenz, Josefine, Wetterich, Sebastian, Jones, B.M., Meyer, Hanno, Bobrov, Anatoly, and Grosse, Guido, 2016, Evidence of multiple thermokarst lake generations from an 11 800-year-old permafrost core on the northern Seward Peninsula, Alaska: Boreas, v. 45, no. 4, p. 584-603.

Lerbekmo, J.F., 2008, The White River ash: largest Holocene plinian tephra: Canadian Journal of Earth Sciences, v. 45, no. 6, p. 693-700.

Lerbekmo, J.F., and Campbell, F.A., 1969, Distribution, composition, and source of the White River Ash, Yukon Territory: Canadian Journal of Earth Sciences, v. 6, no. 1, p. 109-116.

Lerbekmo, J.F., Hanson, L.W., and Campbell, F.A., 1968, Application of particle size distribution to determination of source of a volcanic ash deposit, in International Geological Congress, 23: Proceedings, Prague, 1968, p. 283-295.

Lerbekmo, J.F., Westgate, J.A., Smith, D.G.W., and Denton, G.H., 1975, New data on the character and history of the White River volcanic eruption, Alaska, in Quaternary studies: selected papers from IX INQUA congress: Royal Society of New Zealand Bulletin 0013, p. 203-209.

Lerner, A.H., 2010, Eruption dynamics of the 7.7 ka Driftwood pumice-fall, Makushin Volcano, Alaska: Proceedings of the 23rd Annual Keck Research Symposium in Geology, April 2010, p. 348-353.

Levy, L.B., 2002, A record of late Holocene glacier fluctuations, Ahklun Mountains, southwestern Alaska: Flagstaff, Northern Arizona University M.S. thesis, 71 p.

Levy, L.B., Kaufman, D.S., and Werner, Al, 2004, Holocene glacier fluctuations, Waskey Lake, northeastern Ahklun Mountains, southwestern Alaska: The Holocene, v. 14, p. 185-193.

Lowenstern, J.B., 1993, Evidence for a copper-bearing fluid in magma erupted at the Valley of Ten Thousand Smokes, Alaska: Contributions to Mineralogy and Petrology, v. 114, no. 3, p. 409-421.

Lunt, A.S., 1997, A reconnaissance study of mafic to intermediate intra-arc volcanism in the western Wrangell Volcanic Field, Alaska: Oxford, Miami University Ph.D. dissertation, 150 p.

Mackay, Helen, Hughes, P.D.M., Jensen, B.J.L., Langdon, P.G., Pyne-O’Donnell, S.D.F., Plunkett, Gill, Froese, D.G., Coulter, Sarah, Gardner, J.E., 2016, A mid to late Holocene cryptotephra framework from eastern North America: Quaternary Science Reviews, v. 132, p. 101-113.

Mangan, M.T., Waythomas, C.F., Miller, T.P., and Trusdell, F.A., 2003, Emmons Lake Volcanic Center, Alaska Peninsula: source of the late Wisconsin Dawson tephra, Yukon Territory, Canada: Canadian Journal of Earth Sciences, v. 40, no. 7, p. 925-936.

Mastin, L.G., Schwaiger, Hans, Schneider, D.J., Wallace, K.L., Schaefer, Janet, and Denlinger, R.P., 2013, Injection, transport, and deposition of tephra during event 5 at Redoubt Volcano, 23 March, 2009: Journal of Volcanology and Geothermal Research, v. 259, p. 201-213. 
Matheus, Paul, Begét, J.E., Mason, Owen, and Gelvin-Reymiller, Carol, 2003, Late Pliocene to late Pleistocene environments preserved at the Palisades Site, central Yukon River, Alaska, in Westgate, J.A., ed., Special issue dedicated to Troy Péwé: Quaternary Research, v. 60, no. 1, p. 33-43.

Matthews, J.V., Westgate, J.A., Ovenden, Lynn, Carter, D.L., and Fouch, Thomas, 2003, Stratigraphy, fossils, and age of sediments at the upper pit of the Lost Chicken gold mine: new information on the late Pliocene environment of east central Alaska: Quaternary Research, v. 60, no. 1, p. 9-18.

McConnell, V.S., Begét, J.E., Roach, A.L., Bean, K.W., and Nye, C.J., 1998, Geologic map of the Makushin Volcanic Field, Unalaska Island, Alaska: Alaska Division of Geological \& Geophysical Surveys Report of Investigation 97-20, 2 sheets, scale 1:63,360.

McDowell, P.F., Edwards, M.E., 2001, Evidence of Quaternary climatic variations in a sequence of loess and related deposits at Birch Creek, Alaska: implications for the Stage 5 climatic chronology: Quaternary Science Reviews v. 20, p. 63-76.

McGimsey, R.G., Neal, C.A., and Riley, C.M., 2001, Areal distribution, thickness, mass, volume, and grain size of tephra-fall deposits from the 1992 eruptions of Crater Peak Vent, Mt. Spurr volcano, Alaska: U.S. Geological Survey Open-File Report OF 01-0370, 38 p.

McGimsey, R.G., Richter, D.H., DuBois, G.D., and Miller, T.P., 1992, A postulated new source for the White River Ash, Alaska, in Bradley, D.C., and Ford, A.B., eds., Geologic studies in Alaska by the U.S. Geological Survey, 1990: U.S. Geological Survey Bulletin 1999, p. 212218.

McKay, N.P., 2007, Late Holocene climate at Hallet and Greyling Lakes, central Chugach Range, south-central Alaska: Flagstaff, Northern Arizona University M.S. thesis, 96 p.

Miller, D.M., 1995, Petrogenesis of adjacent calc-alkaline and tholeitic volcanoes on Umnak Island, Aleutian Islands, Alaska: New York, Columbia University Ph.D. dissertation, 476 p.

Miller, D.M., Goldstein, S.L., and Langmuir, C.H., 1994, Cerium/ lead and lead isotope ratios in arc magmas and the enrichment of lead in the continents: Nature, v. 368, no. 6471, p. 514520 .

Miller, D.M., Langmuir, C.H., Goldstein, S.L., and Franks, A.L., 1992, The importance of parental magma composition to calc-alkaline and tholeiitic evolution: evidence from Umnak Island in the Aleutians: Journal of Geophysical Research, v. 97, no. B1, p. 321-343.

Miller, T.P., Waythomas, C.F., and Nye, C. J., 2003, Preliminary geologic map of Kanaga Volcano, Alaska: U.S. Geological Survey Open-File Report OF 03-0113, unpaged, 2 sheets, scale $1: 20,000$. 
Moodie, D.W., Catchpole, A.J.W., and Abel, Kerry, 1992, Northern Athapaskan oral traditions and the White River volcano: Ethnohistory, v. 39, no. 2, p. 148-171.

Monteath, A.J., van Hardenbroek, Maarten, Davies, L.J., Froese, D.G., Langdon, P.G., Xu, Xiaomei, and Edwards, M.E., 2017, Chronology and glass chemistry of tephra and cryptotephra horizons from lake sediments in northern Alaska, USA: Quaternary Research, v. 88, p. 110.

Motyka, R.J., 1983, Increases and fluctuations in thermal activity at Mount Wrangell, Alaska: Fairbanks, University of Alaska Fairbanks unpublished Ph.D. dissertation, 368 p.

Muhs, D.R., Ager, T.A., and Begét, J.E., 2001, Vegetation and paleoclimate of the last interglacial period, central Alaska: Quaternary Science Reviews, v. 20, p. 41-61.

Mullen, P.O., 2012, An archaeological test of the effects of the White River Ash eruptions: Arctic Anthropology, v. 49, p. 35-44.

Mulliken, K.M., 2016, Holocene volcanism and human occupation in the middle Susitna River Valley, Alaska: Fairbanks, University of Alaska Fairbanks M.A. thesis, 234 p.

Naeser, N.D., Westgate, J.A., Hughes, O.L., and Péwé, T.L., 1982, Fission-track ages of late Cenozoic distal tephra beds in the Yukon Territory and Alaska: Canadian Journal of Earth Sciences, v. 19, no. 11, p. 2167-2178.

Nayudu, Y.R., 1964, Volcanic ash deposits in the Gulf of Alaska and problems of correlation of deep-sea ash deposits: Marine Geology, v. 1, no. 3, p. 194-212.

Neal, C.A., McGimsey, R.G., Gardner, C.A., Harbin, M.L., and Nye, C.J., 1995, Tephra-fall deposits from the 1992 eruptions of Crater Peak, Mount Spurr volcano, Alaska: a preliminary report on distribution, stratigraphy, and composition, in Keith, T.E.C., ed., The 1992 eruptions of Crater Peak Vent, Mount Spurr volcano, Alaska: U.S. Geological Survey Bulletin B 2139, p. 65-79.

Neal, C.A., McGimsey, R.G., Miller, T.P., Riehle, J.R., and Waythomas, C.F., 2001, Preliminary volcano-hazard assessment for Aniakchak Volcano, Alaska: U.S. Geological Survey OpenFile Report OF 00-0519, 35 p.

Nicholson, R.S., 2003, The 1931 eruption of Aniakchak volcano, Alaska: Fairbanks, University of Alaska Fairbanks unpublished M.S. thesis, 270 p.

Nicholson, R.S., Gardner, J.E., and Neal, C.A., 2011, Variations in eruption style during the 1931 A.D. eruption of Aniakchak volcano, Alaska: Journal of Volcanology and Geothermal Research, v. 207, no. 3-4, p. 69-82.

Nye, C.J., Keith, T.E.C., Eichelberger, J.C., Miller, T.P., McNutt, S.R., Moran, S., Schneider, D.J., Dehn, J., and Schaefer, J.R., 2002, The 1999 eruption of Shishaldin Volcano, Alaska: monitoring a distant eruption: Bulletin of Volcanology, v. 64, no. 8, p. 507-519. 
Nye, C.J., Swanson, S.E., Avery, V.F., and Miller, T.P., 1994, Geochemistry of the 1989-1990 eruption of Redoubt Volcano: Part I. Whole-rock major- and trace-element chemistry, in Miller, T.P. and Chouet, B.A., eds., The 1989-1990 eruptions of Redoubt Volcano, Alaska: Journal of Volcanology and Geothermal Research, v. 62, no. 1-4, p. 429-452.

Nye, C.J., and Turner, D.L., 1990, Petrology, geochemistry, and age of the Spurr volcanic complex, eastern Aleutian arc: Bulletin of Volcanology, v. 52, no. 3, p. 205-226.

Okuno, Mitsuro, Wada, Keiji, Nakamura, Toshio, Gualtieri, Lyn, Sarata, Brenn, West, Dixie, and Torii, Masayuki, 2012, Holocene Tephra Layers on the Northern Half of Adak Island in the West-Central Aleutian Islands, Alaska, in West, Dixie, Hatfield, Virginia, Wilmerding, Elizabeth, Lefevre, Christine and Gualtieri, Lyn, eds., The People Before: The Geology, Paleoecology and Archaeology of Adak Island, Alaska: Oxford, England, British Archaeological Reports, p. 61-75.

Palais, J.M., and Sigurdsson, Haraldur, 1989, Petrologic evidence of volatile emissions from major historic and pre-historic volcanic eruptions, in Berger, A., Dickenson, R.E., and Kidson, J.W., eds., Understanding climate change: American Geophysical Union Geophysical Monograph 0052, p. 31-53.

Patterson, R.T., Crann, C.A., Cutts, J.A., Mustaphi, C.J.C., Nasser, N.A., Macumber, A.L., Galloway, J.M., Swindles, G.T., and Falck, Hendrik, 2017, New occurrences of the White River Ash (east lobe) in Subarctic Canada and utility for estimating freshwater reservoir effect in lake sediment archives: Palaeogeography, Palaeoclimatology, Palaeoecology, v. 477 , p. 1-9.

Payne, Richard, Blackford, Jeffrey, and van der Plicht, Johannes, 2008, Using cryptotephras to extend regional tephrochronologies: an example from southeast Alaska and implications for hazard assessment: Quaternary Research, v. 69, no. 1, p. 42-55.

Payne, R.J., and Blackford, J.J., 2008, Extending the Late Holocene tephrochronology of the central Kenai Peninsula, Alaska: Arctic, v. 61, no. 3, p. 243-254.

Payne, R.J., and Symeonakis, Elias, 2012, The spatial extent of tephra deposition and environmental impacts from the 1912 Novarupta eruption: Bulletin of Volcanology, no. 74, p. 2449-2458.

Pearce, Christof, Varhelyi, Aron, Wastegard, Stefan, Muschitiello, Francesco, Barrientos, Natalia, O'Regan, Matt, Cronin, T.M., Gemery, Laura, Semiletov, Igor, Backman, Jan, and Jakobsson, Martin, 2017, The 3.6 ka Aniakchak tephra in the Arctic Ocean: a constraint on the Holocene radiocarbon reservoir age in the Chukchi Sea: Climate of the Past, v. 13, no. 4, p. 303-316.

Pearce, N.J.G., Westgate, J.A., Perkins, W.T., and Preece, S.J., 2004, The application of ICP-MS methods to tephrochronological problems: Applied Geochemistry, v. 19, no. 3, p. 289-322. 
Pearce, N.J.G., Westgate, J.A., Preece, S.J., Eastwood, W.J., and Perkins, W.T., 2004, Identification of Aniakchak (Alaska) tephra in Greenland ice core challenges the $1645 \mathrm{BC}$ date for Minoan eruption of Santorini: Geochemistry, Geophysics, Geosystems - G3, v. 5, no. 3, 10 p.

Péwé, T.L., 1975, Quaternary stratigraphic nomenclature in unglaciated central Alaska: U.S. Geological Survey Professional Paper PP 0862, 32 p.

Péwé, T.L., Westgate, J.A., Preece, S.J., Brown, P.M., and Leavitt, S.W., 2009, Late Pliocene Dawson Cut forest bed and new tephrochronological findings in the Gold Hill Loess, east-central Alaska: Geological Society of America Bulletin, v. 121, no. 1-2, p. 294-320.

Pilcher, J.R., Hall, V.A., and McCormac, F.G., 1995, Dates of Holocene Icelandic volcanic eruptions from tephra layers in Irish peats: The Holocene, v. 5, p. 103-110.

Pilcher, J.R., Hall, V.A., and McCormac, F.G., 1996, An outline tephrochronology for the Holocene of the north of Ireland: Journal of Quaternary Science, v. 11, p. 485-494.

Pinney, D.S., 1993, Late Quaternary glacial and volcanic stratigraphy near Windy Creek, Katmai National Park, Alaska: Fairbanks, University of Alaska Fairbanks unpublished M.S. thesis, $185 \mathrm{p}$.

Pinney, D.S., and Begét, J.E., 1991, Late Pleistocene volcanic deposits near the Valley of Ten Thousand Smokes, Katmai National Park, Alask, in Reger, R.D., ed., Short notes on Alaskan geology 1991: Alaska Division of Geological \& Geophysical Surveys Professional Report PR 0111, p. 45-53.

Porter, S.C., 1981, Use of tephrochronology in the Quaternary geology of the United States, in Self, S. and Sparks, R.S.J., eds., Tephra studies: proceedings of the NATO Advanced Study Institute "Tephra studies as a tool in Quaternary research": NATO Scientific Affairs Division NATO advanced study institutes series C 0075, p. 135-160.

Power, J.A., Coombs, M.L., and Freymueller, J.T., eds., 2010, The 2006 eruption of Augustine Volcano, Alaska: U.S. Geological Survey Professional Paper 1769, 667 p., 1 plate, scale $1: 20,000$, and data files.

Praetorius, Summer, Mix, Alan, Jensen, Britta, Froese, Duane, Milne, Glenn, Wolhowe, Matthew, Addison, Jason, and Prahl, Fredrick, 2016, Interaction between climate, volcanism, and isostatic rebound in Southeast Alaska during the last deglaciation: Earth and Planetary Science Letters, v. 452, p. 79-89.

Pratt, R.M., Scheidegger, K.F., and Kulm, L.D., 1973, Volcanic ash from DSDP Site 178, Gulf of Alaska, in Musich, L.F. and Weser, O.E., eds., Initial Reports of the Deep Sea Drilling Project, v. 18: Washington, Government Printing Office, p. 833-834. 
Preece, S.J., 1991, Tephrostratigraphy of the late Cenozoic Gold Hill loess, Fairbanks area, Alaska: Toronto, University of Toronto M.S. thesis, $186 \mathrm{p}$.

Preece, S.J., 1997, Geochemical variation in the less than 5 Ma Wrangell Volcanic Field, Alaska, with an emphasis on the Skookum Creek volcanic complex: Oxford, Miami University unpublished Ph.D. dissertation, 547 p.

Preece, S.J., McGimsey, R.G., Westgate, J.A., Pearce, N.J.G., Hart, W.K., and Perkins, W.T., 2014, Chemical complexity and source of the White River Ash, Alaska and Yukon: Geosphere, v. 10, no.5., p. 1020-1042.

Preece, S.J., Pearce, N.J.G., Westgate, J.A., Froese, D.G., Jensen, B.J.L., and Perkins, W.T., 2011, Old Crow tephra across eastern Beringia: a single cataclysmic eruption at the close of Marine Isotope Stage 6: Quaternary Science Reviews, v. 30, p. 2069-2099.

Preece, S.J., Westgate, J.A., Alloway, B.V., and Milner, M.W., 2000, Characterization, identity, distribution, and source of late Cenozoic tephra beds in the Klondike District of the Yukon, Canada: Canadian Journal of Earth Sciences, v. 37, no. 7, p. 983-996.

Preece, S.J., Westgate, J.A., Froese, D.G., Pearce, N.J.G., and Perkins, W.T., 2011, A catalogue of late Cenozoic tephra beds in the Klondike Goldfields and adjacent areas, Yukon Territory: Canadian Journal of Earth Sciences, v. 48, p. 1386-1418.

Preece, S.J., Westgate, J.A., Stemper, B.A., and Péwé, T.L., 1999, Tephrochronology of late Cenozoic loess at Fairbanks, central Alaska: Geological Society of America Bulletin, v. 111, no. 1, p. 71-90.

Pyne-O'Donnell, S.D.F., Hughes, P.D.M., Froese, D.G., Jensen, B.J.L., Kuehn, S.C., Mallon, Gunnar, Amesbury, M.J., Charman, D.J., Daley, T.J., Loader, N.J., Mauquoy, Dmitri, Street-Perrott, F.A., and Woodman-Ralph, Jonathan, 2012, High-precision ultra-distal Holocene tephrochronology in North America: Quaternary Science Reviews, v. 52, p. 611.

Reger, R.D., Pinney, D.S., Burke, R.M., and Wiltse, M.A., 1996, Catalog and initial analyses of geologic data related to Middle to Late Quaternary deposits, Cook Inlet region, Alaska: Alaska Division of Geological \& Geophysical Surveys Report of Investigation 95-6, 188 p., 6 sheets.

Reinink-Smith, L.M., 1995, Tephra layers as correlation tools of Neogene coal-bearing strata from the Kenai Lowland, Alaska: Geological Society of America Bulletin, v. 107, no. 3, p. 340353.

Reyes, A.V., Froese, D.G., and Jensen, B.J.L., 2010, Permafrost response to last interglacial warming: field evidence from non-glaciated Yukon and Alaska: Quaternary Science Reviews, v. 29, no. 23024, p. 3256-3274. 
Reyes, A.V., Jensen, B.J.L., Zazula, G.D., Ager, T.A., Kuzmina, Svetlana, La Farge, Catherine, and Froese, D.G., 2010, A late-Middle Pleistocene (Marine Isotope Stage 6) vegetated surface buried by Old Crow tephra at the Palisades, interior Alaska: Quaternary Science Reviews, v. 29 , no. 5-6, p. $801-811$.

Reyes, A.V., Zazula, G.D., Kuzmina, Svetlana, Ager, T.A., Froese, D.G., 2011, Identification of last interglacial deposits in eastern Beringia: a cautionary note from the Palisades, interior Alaska: Journal of Quaternary Science, v. 26, no. 3, p. 345-352.

Rich, W.H., and Ball, E.M., 1931, Statistical review of the Alaska salmon fisheries, part II: Chignik to Resurrection Bay: U.S. Bureau of Fisheries Bulletin 46, p. 643-712.

Richter, D.H., Moll-Stalcup, E.J., Miller, T.P., Lanphere, M.A., Dalrymple, G.B., and Smith, R.L., 1994, Eruptive history and petrology of Mount Drum volcano, Wrangell Mountains, Alaska: Bulletin of Volcanology, v. 56, no. 1, p. 29-46.

Richter, D.H., Preece, S.J., McGimsey, R.G., and Westgate, J.A., 1995, Mount Churchill, Alaska: source of the late Holocene White River Ash: Canadian Journal of Earth Sciences, v. 32, no. 6, p. 741-748.

Richter, D.H., Ratte, J.C., Leeman, W.P., and Menzies, Martin, 2000, Geologic map of the McCarthy D-1 Quadrangle, Alaska: U.S. Geological Survey Miscellaneous Investigations Series Map I 2695, unpaged, 1 sheet, scale 1:63,360.

Richter, D.H., Smith, J.G., Schmoll, H.R., and Smith, R.L., 1993, Geologic map of the Nabesna B-6 Quadrangle, south-central Alaska: U.S. Geological Survey Geological Quadrangle Map GQ 1688, unpaged, 1 sheet, scale 1:63,360.

Richter, D.H., Smith, R.L., Yehle, L.A., and Miller, T.P., 1979, Geologic map of the Gulkana A-2 quadrangle, Alaska: U.S. Geological Survey Geological Quadrangle Map GQ 1520, unpaged, 1 plate, scale 1:63,360.

Richter, D.H., Waythomas, C.F., McGimsey, R.G., and Stelling, P.L., 1998, Geologic map of Akutan Island, Alaska: U.S. Geological Survey Open-File Report OF 98-0135, 22 p., 1 sheet, scale $1: 48,000$.

Riehle, J.R., 1985, A reconnaissance of the major Holocene tephra deposits in the upper Cook Inlet region, Alaska: Journal of Volcanology and Geothermal Research, v. 26, no. 1-2, p. 37-74.

- _ 1994, Heterogeneity, correlatives, and proposed stratigraphic nomenclature of Hayes tephra set H, Alaska: Quaternary Research, v. 41, no. 3, p. 285-288.

Riehle, J.R., Ager, T.A., Reger, R.D., Pinney, D.S., and Kaufman, D.S., 2006, Stratigraphic and compositional complexities of the late Quaternary Lethe tephra in south-central Alaska: Quaternary International, v. 138, no. 1, p. 210-228. 
Riehle, J.R., Bowers, P.M., and Ager, T.A., 1990, The Hayes tephra deposits, an upper Holocene marker horizon in south- central Alaska: Quaternary Research, v. 33, no. 3, p. 276-290.

Riehle, J.R., Champion, D.E., Brew, D.A., and Lanphere, M.A., 1992, Pyroclastic deposits of the Mount Edgecumbe volcanic field, Southeast Alaska: eruptions of a stratified magma chamber: Journal of Volcanology and Geothermal Research, v. 53, no. 1, p. 117-144.

Riehle, J.R., Dumond, D.E., Meyer, C.E., and Schaaf, J.M., 2000, Tephrochronology of the Brooks River Archaeological District, Katmai National Park and Preserve, Alaska: what can and cannot be done with tephra deposits, in McGuire, W.J., Griffiths, D.R., Hancock, P.L., and Stewart, I.S., eds., The archaeology of geological catastrophes: Geological Society, London Special Publication 171, p. 245-266.

Riehle, J.R., Mann, D.H., Peteet, D.M., Engstrom, D.R., Brew, D.A., and Meyer, C.E., 1992, The Mount Edgecumbe tephra deposits: a marker horizon in southeastern Alaska near the Pleistocene-Holocene boundary: Quaternary Research, v. 37, no. 2, p. 183-202.

Riehle, J.R., Meyer, C.E., Ager, T.A., Kaufman, D.S., and Ackerman, R.E., 1987, The Aniakchak tephra deposit, a late Holocene marker horizon in western Alaska, in Hamilton, T.D. and Galloway, J.P., eds., Geologic studies in Alaska by the U.S. Geological Survey during 1986: U.S. Geological Survey Circular C 0998, p. 19-22.

Riehle, J.R., Meyer, C.E., and Miyaoka, R.T., 1999, Data on Holocene tephra (volcanic ash) deposits in the Alaska Peninsula and lower Cook Inlet region of the Aleutian volcanic arc, Alaska: U.S. Geological Survey Open-File Report 99-135.

Riehle, J.R., Waitt, R.B., Meyer, C.E., and Calk, L.C., 1998, Age of formation of Kaguyak Caldera, eastern Aleutian Arc, Alaska, estimated by tephrochronology, in Gray, J.E. and Riehle, J.R., eds., Geologic studies in Alaska by the U.S. Geological Survey, 1996: U.S. Geological Survey Professional Paper PP 1595, p. 161-168.

Robinson, S.D., 2001, Extending the Late Holocene White River Ash distribution, northwestern Canada: Arctic, v. 54, no. 2, p. 157-161.

Romick, J.D., Kay, S.M., and Kay, R.W., 1992, The influence of amphibole fractionation on the evolution of calc-alkaline andesite and dacite tephra from the central Aleutians, Alaska: Contributions to Mineralogy and Petrology, v. 112, no. 1, p. 101-118.

Sandhu, A.S., Westgate, J.A., Preece, S.J., and Froese, D.G., 2000, Glass-fission-track ages of late Cenozoic distal tephra beds in the Klondike district, Yukon Territory, in Emond, D.S., and Weston, L.H., eds., Yukon exploration and geology 2000: Exploration and Geological Services Division, Yukon, Indian and Northern Affairs Canada, p. 247-256.

Schaefer, J.R.G., 2002, Stratigraphy, major oxide geochemistry, and 40Ar/39Ar geochronology of a tephra section near Tok, Alaska: Fairbanks, University of Alaska Fairbanks unpublished M.S. thesis, $62 \mathrm{p}$. 
Schaefer, J.R., ed., 2012, The 2009 eruption of Redoubt Volcano, Alaska, with contributions by Bull, Katharine, Cameron, Cheryl, Coombs, Michelle, Diefenbach, Angie, Lopez, Taryn, McNutt, Steve, Neal, Christina, Payne, Allison, Power, John, Schneider, Dave, Scott, William, Snedigar, Seth, Thompson, Glenn, Wallace, Kristi, Waythomas, Chris, Webley, Peter, and Werner, Cynthia: Alaska Division of Geological \& Geophysical Surveys Report of Investigation 2011-5, 45 p.

Schaefer, J.R., and Wallace, K.L., 2012, Ash fall contour map of the 2009 eruption of Redoubt Volcano, Alaska: Digital shapefiles of contours and sample locations: Alaska Division of Geological \& Geophysical Surveys Miscellaneous Publication 143, 1 DVD.

Scheidegger, K.F., and Kulm, L.D., 1975, Late Cenozoic volcanism in the Aleutian Arc: information from ash layers in the northeastern Gulf of Alaska: Geological Society of America Bulletin, v. 86 , no. 10 , p. $1407-1412$.

Scheidegger, K.F., Corliss, J.B., Jezek, P.A., and Ninkorich, D., 1980, Compositions of deep sea ash layers derived from North Pacific volcanic arcs: variations in time and space: Journal of Volcanology and Geothermal Research, v. 7, no. 1-2, p. 107-137.

Scheidegger, K.F., Jezek, P.A., and Ninkovich, D., 1978, Chemical and optical studies of glass shards in Pleistocene and Pliocene ash layers from DSDP site 192, northwest Pacific Ocean: Journal of Volcanology and Geothermal Research, v. 4, p. 99-116.

Schiff, C.J., Kaufman, D.S., Wallace, K.L., and Ketterer, M.E., 2010, An improved proximal tephrochronology of Redoubt Volcano, Alaska: Journal of Volcanology and Geothermal Research, v. 193, no. 3/4, p. 203-214.

Schirrmeister, Lutz, Meyer, Hanno, Andreev, Andrei, Wetterich, Sebastian, Kienast, Frank, Bobrov, Anatoly, Fuchs, Margaret, Sierralta, Melanie, and Herzschuh, Ulrike, 2016, Late Quaternary paleoenvironmental records from the Chatanika River valley near Fairbanks (Alaska): Quaternary Science Reviews, v. 147, no. 1, p. 1-20.

Schnetzler, C.C., Doiron, S.D., Walter, L.S., and Krueger, A.J., 1994, Satellite measurement of sulfur dioxide from the Redoubt eruptions of 1989-1990, in Miller, T.P., ed., The 1989-1990 eruptions of Redoubt Volcano, Alaska: Journal of Volcanology and Geothermal Research, v. 62 , no. $1-4$, p. $353-357$.

Scott, W.E., and McGimsey, R.G., 1991, Mass, distribution, grain size, and origin of 1989-1990 tephra-fall deposits of Redoubt Volcano, Alaska [abs.], in Casadevall, T.J., ed., First international symposium on volcanic ash and aviation safety: U.S. Geological Survey Circular C 1065, p. 39.

- - - 1994, Character, mass, distribution, and origin of tephra-fall deposits of the 1989-1990 eruption of Redoubt volcano, south-central Alaska, in Miller, T.P. and Chouet, B.A., eds., 
The 1989-1990 eruptions of Redoubt Volcano, Alaska: Journal of Volcanology and Geothermal Research, v. 62, no. 1, p. 251-272.

Shacklette, H.T., and Rubin, Meyer, 1969, Radiocarbon dating of ash deposits on Amchitka Island, Alaska, in Geological Survey research 1969, Chapter B: U.S. Geological Survey Professional Paper PP 0650-B, p. B81-B83.

Siebert, Lee, Begét, J.E., and Glicken, Harry, 1995, The 1883 and late-prehistoric eruptions of Augustine volcano, Alaska: Journal of Volcanology and Geothermal Research, v. 66, no. 1, p. 367-395.

Stelling, P., Begét, J., Nye, C., Gardner, J., Devine, J.D., and George, R.M.M., 2002, Geology and petrology of ejecta from the 1999 eruption of Shishaldin Volcano, Alaska: Bulletin of Volcanology, v. 64, no. 8, p. 548-561.

Stelling, Pete, Begét, J.E., Gardner, J.E., and Schaefer, J.R., 2014, Preliminary volcano-hazard assessment for Fisher volcano, Unimak Island, Alaska: Alaska Division of Geological \& Geophysical Surveys Report of Investigation 2014-5, 32 p., 1 sheet, scale 1:500,000.

Stelling, Pete, Gardner, J.E., and Begét, James, 2005, Eruptive history of Fisher Caldera, Alaska, USA: Journal of Volcanology and Geothermal Research, v. 139, no. 3-4, p. 163-183.

Stelling, P.L., 2003, Volcanism on Unimak Island, Alaska, USA: a special focus on Shishaldin and Fisher volcanoes: Fairbanks, University of Alaska Fairbanks unpublished Ph.D. dissertation, 193 p. and one CD-ROM.

Stevens, D.S.P., 2012, Pre-1912 glacial and volcanic history near Windy Creek, Katmai National Park and Preserve, Alaska: National Park Service, Alaska Park Science v. 11, no. 1, p. 4651.

Stihler, S.D., 1991, Paleomagnetic investigations of seismic and volcanic activity recorded in the sediments of Skilak Lake, Alaska: Fairbanks, University of Alaska Fairbanks unpublished M.S. thesis, $120 \mathrm{p}$.

Stilwell, K.B., 1995, Late Quaternary glacial geology, shoreline morphology, and tephrochronology of the Iliamna/Naknek/Brooks Lake area, Southwestern Alaska: Logan, Utah State University unpublished M.S. thesis, $176 \mathrm{p}$.

Swanson, S.E., Harbin, M.L., and Riehle, J.R., 1995, Use of volcanic glass from ash as a monitoring tool: an example from the 1992 eruptions of Crater Peak, Mount Spurr volcano, Alaska, in Keith, T.E.C., ed., The 1992 eruptions of Crater Peak Vent, Mount Spurr volcano, Alaska: U.S. Geological Survey Bulletin B 2139, p. 129-137.

Swanson, S.E., Nye, C.J., Miller, T.P., and Avery, V.F., 1994, Geochemistry of the 1989-1990 eruption of Redoubt Volcano: Part II, Evidence from mineral and glass chemistry, in Miller, 
T.P., ed., The 1989-1990 eruptions of Redoubt Volcano, Alaska: Journal of Volcanology and Geothermal Research, v. 62, no. 1-4, p. 453-468.

Tannenbaum, T.G., 1996, Holocene tephra stratigraphy on northern Kodiak Island, Alaska: Fairbanks, University of Alaska Fairbanks M.S. thesis, 165 p.

Tappen, C.M., Webster, J.D., Mandeville, C.W., and Roderick, David, 2009, Petrology and geochemistry of ca. 2100-1000 a.B.P. magmas of Augustine volcano, Alaska, based on analysis of prehistoric pumiceous tephra: Journal of Volcanology and Geothermal Research, v. 183, no. 1/2, p. 42-62.

Till, A.B., Yount, M.E., and Bevier, M.L., 1994, The geologic history of Redoubt Volcano, Alaska, in Miller, T.P. and Chouet, B.A., eds., The 1989-1990 eruptions of Redoubt Volcano, Alaska: Journal of Volcanology and Geothermal Research, v. 62, no. 1, p. 11-30.

Triplehorn, D.M., Turner, D.L., and Naeser, C.W., 1977, K-Ar and fission-track dating of ash partings in Tertiary coals from the Kenai Peninsula, Alaska: A radiometric age for the Homerian-Clamgulchian stage boundary: Geological Society of America Bulletin, v. 88, no. 8, p. 1156-1160.

Turner, D.L., Triplehorn, D.M., Naeser, C.W., and Wolfe, J.A., 1980, Radiometric dating of ash partings in Alaskan coal beds and upper Tertiary paleobotanical stages: Geology, v. 8, no. 2, p. 92-96.

Unema, J.A., Ort, M.H., Larsen, J.F., Neal, C.A., and Schaefer, J.R., 2016, Water-magma interaction and plume processes in the 2008 Okmok eruption, Alaska: GSA Bulletin, 15 p.

van den Bogaard, Christel, and Schmincke, Hans-Ulrich, 2002, Linking the North Atlantic to central Europe: A high-resolution Holocene tephrochronological record from northern Germany: Journal of Quaternary Science, v. 17, p. 3-20.

VanderHoek, Richard, and Myron, Rachel, 2004, An archaeological overview and assessment of Aniakchak National Monument and Preserve: U.S. National Park Service Research/ Resources Management Report AR/CRR-2004-47.

Van Eaton, A.R., Mastin, L.G., Herzog, Michael, Schwaiger, H.F., Schneider, D.J., Wallace, K.L., and Clarke, A.B., 2015, Hail formation triggers rapid ash aggregation in volcanic plumes: Nature Communications, v. 6, no. 7860, 7 p.

Waitt, R.B., and Begét, J.E., 2009, Volcanic processes and geology of Augustine Volcano, Alaska: U.S. Geological Survey Professional Paper 1762, 78 p., 2 plates, scale 1:25,000.

Wallace, K.L., 2003, Characterization and discrimination of Holocene tephra-fall deposits, Mount Spurr volcano, Alaska: Flagstaff, Northern Arizona University unpublished M.S. thesis, 169 p. 
Wallace, K.L., Coombs, M.L., Hayden, L.A., and Waythomas, C.F., 2014, Significance of a nearsource tephra-stratigraphic sequence to the eruptive history of Hayes Volcano, southcentral Alaska: U.S. Geological Survey Scientific Investigations Report 2014-5133, 32 p.

Wallace, K.L., Neal, C.A., and McGimsey, R.G., 2010, Timing, distribution, and character of tephra fall from the 2005-2006 eruption of Augustine Volcano, chapter 9, in Power, J.A., Coombs, M.L., and Freymueller, J.T., eds., The 2006 eruption of Augustine Volcano, Alaska: U.S. Geological Survey Professional Paper 1769, p. 187-217 and spreadsheet.

Wallace, K.L., Schaefer, J.R., and Coombs, M.L., 2013, Character, mass, distribution, and origin of tephra-fall deposits from the 2009 eruption of Redoubt Volcano, Alaska - Highlighting the significance of particle aggregation: Journal of Volcanology and Geothermal Research, v. 259, p. 145-169.

Ward, B.C., Bond, J.D., Froese, Duane, and Jensen, Britta, 2008, Old Crow tephra (140+/-10 ka) constrains penultimate Reid glaciation in central Yukon Territory: Quaternary Science Reviews, v. 27, p. 1909-1915.

Watson, E.J., Kolaczek, P., Slowinski, M., Swindles, G.T., Marcisz, K., Galka, M. and Lamentowicz, M., 2017, First discovery of Holocene Alaskan and Icelandic tephra in Polish peatlands: Journal of Quaternary Science, v. 32, no. 4, p. 457-462.

Watson, E.J., Swindles, G.T., Lawson, I.T., Savov, I.P., and Wastegård, S., 2017, The presence of Holocene cryptotephra in Wales and southern England: Journal of Quaternary Science, v. 32 , no. 4 , p. $493-500$.

Waythomas, C.F., 1990, Quaternary geology and late-Quaternary environments of the Holitna Lowland and Chuilnuk-Kiokluk Mountains region, interior southwestern Alaska: Boulder, University of Colorado Ph.D. dissertation, 305 p.

Waythomas, C.F., 2015, Geomorphic consequences of volcanic eruptions in Alaska: A review: Geomorphology, v. 246, p. 123-145.

Waythomas, C.F., Dorava, J.M., Miller, T.P., Neal, C.A., and McGimsey, R.G., 1997, Preliminary volcano-hazard assessment for Redoubt Volcano, Alaska: U.S. Geological Survey OpenFile Report OF 97-857, 40 p., 1 plate, scale unknown.

Waythomas, C.F., and Miller, T.P., 2002, Preliminary volcano-hazard assessment for Hayes volcano, Alaska: U.S. Geological Survey Open-File Report OF 02-0072, 33 p.

Waythomas, C.F., Miller, T.P., and Mangan, M.T., 2006, Preliminary volcano hazard assessment for the Emmons Lake volcanic center, Alaska: U.S. Geological Survey Scientific Investigations Report 2006-5248, 41 p.

Waythomas, C.F., and Nye, C.J., 2002, Preliminary volcano-hazard assessment for Mount Spurr Volcano, Alaska: U.S. Geological Survey Open-File Report 2001-482, 40 p. 
West, K.D., 2007, Resedimentation of the late Holocene White River ash, Yukon Territory, Canada, and Alaska, USA: Ottawa, Canada, Carleton University Ph.D. dissertation, 269 p.

West, K.D., and Donaldson, J.A., 2001, Resedimentation of the late Holocene White River tephra, Yukon Territory and Alaska: Yukon exploration and geology, p. 239-247.

Westgate, J.A., 1982, Discovery of a large-magnitude, late Pleistocene volcanic eruption in Alaska: Science, v. 218, no. 4574, p. 789-790.

Westgate, J.A., 1989, Isothermal plateau fission-track ages of hydrated glass shards from silicic tephra beds: Earth and Planetary Science Letters, v. 95, no. 3, p. 226-234.

Westgate, J.A., Hamilton, T.D., and Gorton, M.P., 1983, Old Crow tephra: a new late Pleistocene stratigraphic marker across North-central Alaska and western Yukon Territory: Quaternary Research, v. 19, no. 1, p. 38-54.

Westgate, J.A., Pearce, G.W., Preece, S.J., Schweger, C.E., Morlan, R.E., Pearce, N.J.G., and Perkins, T.W., 2013, Tephrochronology, magnetostratigraphy and mammalian faunas of Middle and Early Pleistocene sediments at two sites on the Old Crow River, northern Yukon Territory, Canada: Quaternary Research, v. 79, no. 1, p. 75-85.

Westgate, J.A., and Pearce, N.J.G., 2017, Age of some Pleistocene interglacial beds and associated fossils in eastern Beringia defined by fission tracks in glass shards of Chester Bluff tephra: Quaternary Research, v. 88, no. 1, p. 152-159.

Westgate, J.A., Perkins, W.T., Fuge, R., Pearce, N.J.G., and Wintle, A.G., 1994, Trace-element analysis of volcanic glass shards by laser ablation inductively coupled plasma mass spectrometry: application to tephrochronological studies: Applied Geochemistry, v. 9, no. 3, p. 323-335.

Westgate, J.A., Preece, S.J., Froese, D.G., Pearce, N.J.G., Roberts, R.G., Demuro, M., Hart, W.K., and Perkins, W., 2007, Changing ideas on the identity and stratigraphic significance of the Sheep Creek tephra beds in Alaska and the Yukon Territory, northwestern Alaska: Quaternary International, v. 178, no. 1, p. 183-209.

Westgate, J.A., Preece, S.J., Froese, D.G., Telka, A.M., Storer, J.E., Pearce, N.J.G., Enkin, R.J., Jackson, L.E. Jr., LeBarge, W., and Perkins, W.T., 2009, Gold Run Tephra: a middle Pleistocene stratigraphic and paleoenvironmental marker across west-central Yukon Territory, Canada: Canadian Journal of Earth Sciences, v. 46, no. 6, p. 465-478.

Westgate, J.A., Preece, S.J., Froese, D.G., Walter, R.C., Sandhu, A.S., and Schweger, C.E., 2001, Dating Early and Middle (Reid) Pleistocene glaciations in central Yukon by tephrochronology: Quaternary Research, v. 56, no. 3, p. 335-348. 
Westgate, J.A., Preece, S.J., and Jackson Jr., L.E., 2011, Revision of the tephrostratigraphy of the lower Sixtymile River area, Yukon Territory, Canada: Canadian Journal of Earth Sciences, v. 48 , no. 3 , p. $695-701$.

Westgate, J.A., Preece, S.J., Kotler, Erica, and Hall, Sheila, 2000, Dawson Tephra: a prominent stratigraphic marker of late Wisconsinan age in west-central Yukon, Canada: Canadian Journal of Earth Sciences, v. 37, no. 4, p. 621-627.

Westgate, J.A., Preece, S.J., and Péwé, T.L., 2003, The Dawson Cut Forest Bed in the Fairbanks area, Alaska, is about two million years old, in Westgate, J.A., ed., Special issue dedicated to Troy Péwé: Quaternary Research, v. 60, no. 1, p. 2-8.

Westgate, J.A., Preece, S.J., Sandhu, A.S., and Froese, D.G., 2000, Update on the late Cenozoic tephrochronology of the Gold Hill loess at Fairbanks, Alaska, and correlation with the Klondike goldfields in the Yukon [abs.], in Troy Péwé Memorial Workshop: Paleoclimates and Paleoenvironments in Eastern Beringia and the Bering Land Bridge, Fairbanks, Alaska, August 21-24, 2000: Alaska Quaternary Center, University of Alaska Fairbanks.

Westgate, J.A., Stemper, B.A., and Péwé, T.L., 1990, A 3-my record of Pliocene-Pleistocene loess in interior Alaska: Geology, v. 18, p. 858-861.

Westgate, J.A., Walter, R.C., Pearce, G.W., and Gorton, M. ., 1985, Distribution, stratigraphy, petrochemistry and palaeomagnetism of the late Pleistocene Old Crow tephra in Alaska and the Yukon: Canadian Journal of Earth Sciences, v. 22, no. 6, p. 893-906.

Westgate, John, 1988, Isothermal plateau fission-track age of the late Pleistocene Old Crow Tephra, Alaska: Geophysical Research Letters, v. 15, no. 4, p. 376-379.

Wetterich, Sebastian, Grosse, Guido, Schirrmeister, Lutz, Andreev, A.A., Bobrov, A.A., Kienast, Frank, Bigelow, N.H., and Edwards, M.E., 2012, Late Quaternary environmental and landscape dynamics revealed by a pingo sequence on the northern Seward Peninsula, Alaska: Quaternary Science Reviews, v. 39, p. 26-44.

Wilcox, R.E., 1959, Some effects of recent volcanic ash falls with special reference to Alaska, in Investigations of Alaskan volcanoes: U.S. Geological Survey Bulletin B 1028-N, p. 409-476, 5 sheets, scale unknown.

Williams, Howel and McBirney, A.R., 1979, Volcanology: San Francisco, Freeman, Cooper and Company, $397 \mathrm{p}$.

Wolf, K.J., 1995, Magmatic behavior during the 1989-1990 eruption of Redoubt Volcano, Alaska: Fairbanks, University of Alaska Fairbanks unpublished M.S. thesis, 188 p.

Wolfe, B.A., 2001, Paleohydrology of a catastrophic flood release from Okmok caldera and postflood eruption history at Okmok Volcano, Umnak Island, Alaska: Fairbanks, University of Alaska Fairbanks unpublished M.S. thesis, 100 p. 
Wong, L.J., 2004, Physical volcanology of a sub-plinian and phreatomagmatic eruption at Okmok Volcano, Alaska: implications for explosive mafic volcanism: Fairbanks, University of Alaska Fairbanks unpublished M.S. thesis, 117 p.

Wong, L.J., and Larsen, J.F., 2010, The Middle Scoria sequence: A Holocene violent strombolian, subplinian, and phreatomagmatic eruption of Okmok volcano, Alaska: Bulletin of Volcanology, v. 72, p. 17-31.

Wright, T.L., 1971, Investigations at active volcanoes [abs.]: Eos, v. 52, no. 5, p. 57-62.

Yalcin, K.B., 2005, Glaciochemical records from the St. Elias Mountains, Yukon, Canada: Durham, University of New Hampshire Ph.D. dissertation, 269 p.

Yalcin, Kaplan, Wake, C.P., and Germani, M.S., 2003, A 100-year record of North Pacific volcanism in an ice core from Eclipse Icefield, Yukon Territory, Canada: Journal of Geophysical Research, v. 108, no. 1, p. 12.

Yount, M.E., Miller, T.P., Emanuel, R.P., and Wilson, F.H., 1985, Eruption in an ice-filled caldera, Mount Veniaminof, Alaska Peninsula, in Bartsch-Winkler, Susan and Reed, K.M., eds., The United States Geological Survey in Alaska: accomplishments during 1983: U.S. Geological Survey Circular C 0945, p. 58-60.

Zander, P.D., Kaufman, D.S., Kuehn, S.C., Wallace, K.L., and Anderson, R.S., 2013, Early and late Holocene glacial fluctuations and tephrostratigraphy, Cabin Lake, Alaska: Journal of Quaternary Science, v. 28, no. 8, p. 761-771.

Zimmer, M.M., Plank, Terry, Hauri, E.H., Yogodzinski, G.M., Stelling, Peter, Larsen, Jessica, Singer, Brad, Jicha, Brian, Mandeville, Charles, and Nye, C.J., 2010, The role of water in generating the calc-alkaline trend: new volatile data for Aleutian magmas and a new tholeiitic index: Journal of Petrology, v. 5, no. 12, p. 2411, 2444. 